\title{
TGF- $\beta$ Family Signaling in Ductal Differentiation and Branching Morphogenesis
}

\author{
Kaoru Kahata, ${ }^{1}$ Varun Maturi, ${ }^{1,2}$ and Aristidis Moustakas ${ }^{1,2}$ \\ ${ }^{1}$ Ludwig Institute for Cancer Research, Science for Life Laboratory, Uppsala University, \\ SE-751 24 Uppsala, Sweden \\ ${ }^{2}$ Department of Medical Biochemistry and Microbiology, Science for Life Laboratory, Uppsala University, \\ SE-751 23 Uppsala, Sweden \\ Correspondence: aris.moustakas@imbim.uu.se
}

\begin{abstract}
Epithelial cells contribute to the development of various vital organs by generating tubular and/or glandular architectures. The fully developed forms of ductal organs depend on processes of branching morphogenesis, whereby frequency, total number, and complexity of the branching tissue define the final architecture in the organ. Some ductal tissues, like the mammary gland during pregnancy and lactation, disintegrate and regenerate through periodic cycles. Differentiation of branched epithelia is driven by antagonistic actions of parallel growth factor systems that mediate epithelial-mesenchymal communication. Transforming growth factor- $\beta$ (TGF- $\beta$ ) family members and their extracellular antagonists are prominently involved in both normal and disease-associated (e.g., malignant or fibrotic) ductal tissue patterning. Here, we discuss collective knowledge that permeates the roles of TGF- $\beta$ family members in the control of the ductal tissues in the vertebrate body.
\end{abstract}

\section{TGF- $\beta$ FAMILY MEMBERS IN DUCTAL MORPHOGENESIS AND EPITHELIAL- MESENCHYMAL INTERACTIONS}

Ther he epithelial morphogenetic potential of the animal body is extensive and leads to the generation of tissues that line the body surface, such as skin, and to the generation of diverse epithelia that line the secretorylumen of various glandular organs. Epithelia in such organs have dedicated functions, such as digestion of food (gastrointestinal tract), deposition of nutrients and detoxification (liver), respiration (lung), filtering of the blood and excretion (kidney and bladder), and other specialized functions, such as secretion (e.g., by mammary and prostate glands).
A general developmental principle in epithelial organs is their origin from primordial epithelial buds, whose cells proliferate and invade the surrounding mesenchyme, generating tubular projections away from the bud and into the mesenchyme (Hogan 1996; Ball and Risbridger 2001). These tubular extensions then receive inductive signals, including transforming growth factor- $\beta$ (TGF- $\beta$ ) family signals, provided by the interacting mesenchymal cells. The tubular branches often generate complex tree-like patterns that characterize many glandular organs, as is the case for, for example, lung, prostate, and kidney organogenesis under the control of activin signaling (Ball and Ris-

Editors: Rik Derynck and Kohei Miyazono

Additional Perspectives on The Biology of the TGF- $\beta$ Family available at www.cshperspectives.org

Copyright (C) 2018 Cold Spring Harbor Laboratory Press; all rights reserved; doi: 10.1101/cshperspect.a031997

Cite this article as Cold Spring Harb Perspect Biol 2018;10:a031997 
K. Kahata et al.

bridger 2001). Associated with the epithelialmesenchymal interactions that provide signals for epithelial differentiation, epithelial cells show plasticity in their differentiation and are able to transdifferentiate into other cell types, such as mesenchymal cells through epithelialmesenchymal transition (EMT) (Hay 1995; Lim and Thiery 2012). The inverse process of mesenchymal-epithelial transition (MET) is also relevant in this context, and attests to the plastic nature of the differentiation programs that govern epithelial and mesenchymal cells (Nieto 2013).

Additional general principles that govern the actions of the TGF- $\beta$ family members during specification of epithelial tissues include (1) the generation of activity gradients by extracellular antagonists and proteases that cleave and activate ligands from their proligand precursors, or cleave and inactivate ligand antagonists (De Robertis 2009); (2) the availability of signaling receptors on target cells and proximity of these cells to adjacent cells and tissue that maintain inductive potential (Oshimori and Fuchs 2012); and (3) the competence of target cells and tissue to respond to TGF- $\beta$ family ligands, defined by the expression pattern of transcription factors and chromatin modifiers that poise target genes to be rapidly or sustainably regulated by incoming TGF- $\beta$ family signals, such as Smads (Massagué 2012). On completion of organogenesis, TGF- $\beta$ family members contribute to the homeostatic maintenance of the epithelial tissues. Additionally, during homeostatic perturbance in response to pathological damage, such as in fibrosis or cancer, the TGF$\beta$ family ligands continue playing critical roles (Massagué 2012). In this review, we will mainly focus on normal processes of differentiation and organogenesis.

\section{THE TGF- $\beta$ FAMILY IN GLANDULAR ORGAN DEVELOPMENT AND EMT}

\section{Mammary Gland}

The mammary gland is an exocrine organ that develops as a skin appendage and is patterned morphogenetically through mechanisms that are common to other exocrine glands, such as prostate, salivary, and sebaceous glands (McNairn et al. 2013). Its development in the embryo is initiated by the formation of a mammary line, thickening of ectoderm placodes, and local epithelial cell movement, leading to formation of the mammary bud (McNairn et al. 2013). Regulated by epithelial-mesenchymal interactions, the placodes descend into the underlying mesenchyme and produce the rudimentary ductal structure of the gland that is present at birth (McNairn et al. 2013). Subsequent development occurs in response to hormonal regulation during pubertal growth, pregnancy, lactation, and involution (Fig. 1) (Wakefield et al. 2001). Puberty initiates branching morphogenesis, which requires growth hormone (GH) and estrogen, as well as insulin-like growth factor 1 (IGF-1), to create a ductal tree that fills the fat pad (Fig. 1). Upon pregnancy, the combined actions of progesterone and prolactin generate alveoli, which secrete milk during lactation (Macias and Hinck 2012). Lack of demand for milk at weaning initiates the process of involution, whereby the gland is remodeled back to its prepregnancy state (Macias and Hinck 2012). These processes require numerous signaling pathways with distinct regulatory functions at different stages of gland development. Signaling pathways also regulate a subpopulation of mammary stem cells that fuel the dramatic changes in the gland occurring with each pregnancy (Macias and Hinck 2012). Diverse are also the functions of the TGF- $\beta$ family in mammary gland development and associated disease, such as breast cancer (Wakefield et al. 2001). We therefore summarize only key observations and highlight avenues for future investigation and deeper understanding.

Within the TGF- $\beta$ family, bone morphogenetic proteins (BMPs) promote the morphogenesis of the mammary gland, whereas TGF- $\beta$ s act as negative regulators (Fig. 1). In mice, BMP-4 acts on the mammary mesenchyme to promote expression of the transcription factor Msx2 (Fig. 1) (Hens et al. 2007). Msx 2 then helps patterning the adjacent epidermis so that hair follicles are excluded from the perimammary space where the nipples will form (Hens et al. 2007). The 


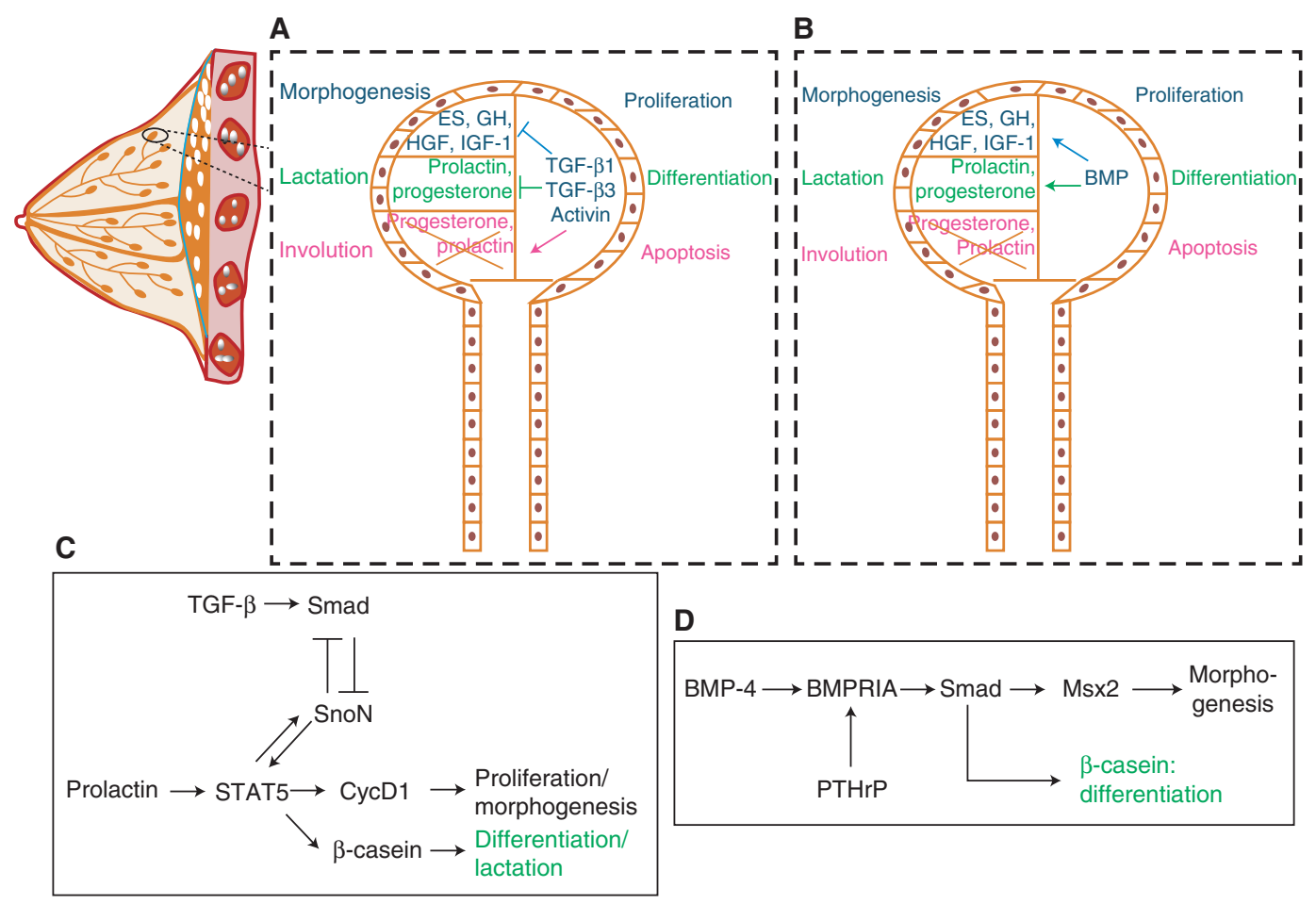

Figure 1. Role of the TGF- $\beta$ family in mammary gland development and maturation. $(A)$ Morphogenesis of a ductal tree in the mammary gland proceeds with epithelial cell proliferation, which is inhibited by TGF- $\beta 1$, TGF- $\beta 3$, and activins (TGF- $\beta 2$ is not well-expressed during breast morphogenesis), by blocking hepatocyte growth factor (HGF), growth hormone (GH), estrogen (ES), and insulin-like growth factor 1 (IGF-1) expression and activities. TGF- $\beta 1$, TGF- $\beta 3$, and activins also block differentiation in ductal trees by inhibiting the actions of progesterone and prolactin, thus repressing colostrum production. These TGF- $\beta$ members induce apoptosis during involution by inhibiting the survival signals provided by progesterone and prolactin. $(B)$ Bone morphogenetic proteins (BMPs) play an opposite role to TGF- $\beta$ by promoting mammary epithelial cell proliferation through induction of HGF, GH, ES, and IGF-1 expression. BMPs also promote lactation by inducing progesterone and prolactin expression and signaling, which lead to terminal differentiation. The role of BMPs during involution is unclear. $(C)$ More detailed TGF- $\beta$ signaling that promotes some of the biological effects shown in panel $A$. TGF- $\beta$ induces Smad signaling, which represses SnoN expression and, in turn, promotes signal transducer and activator of transcription 5 (STAT5) activation. STAT5 is also activated by prolactin signaling and triggers expression of SnoN, cyclin D1 (CycD1), and $\beta$-casein. SnoN opposes the action of TGF- $\beta$ signaling. CycD1 promotes the cell cycle and controls morphogenesis, and $\beta$-casein is an important milk protein expressed at terminal differentiation during lactation. $(D)$ More detailed BMP signaling pathway that mediates some biological effects shown in panel B. BMP-4 activates BMPRIA signaling, and parathyroid hormone-related protein (PTHrP) induces expression of this BMP receptor, resulting in Smad signaling, which induces expression of the transcriptional regulator Msx2. BMP signaling also induces $\beta$-casein expression, marking terminal differentiation during the lactation phase.

ability of the mammary mesenchyme to respond to BMP-4 is regulated by the parathyroid hormone-related protein $(\mathrm{PTHrP})$, which induces expression of the BMP type I receptor BMPRIA by mesenchymal cells (Fig. 1). In the absence of BMP-4, the mammary buds fail to develop fully and their branching morphogenesis is perturbed (Hens et al. 2007). BMPs also promote mammary ductal morphogenesis at later stages, as is apparent by studies of the extracellular BMP ligand accessory protein, twisted gastrulation (Twsg) (Forsman et al. 2013). Twsg is expressed 
K. Kahata et al.

only in myoepithelial cells and in a few cells of the developing bud (Forsman et al. 2013). Inactivation of the Twsg gene in mice causes a dramatic block in branching morphogenesis and terminal alveolar lumen differentiation (Forsman et al. 2013). This correlates with reduced BMP signaling, including low Smad activity in the gland, suggesting that Twsg contributes to BMP ligand presentation to its receptors (Forsman et al. 2013). In three-dimensional polarized mammary epithelial cultures, cells lose their polarity and start growing abnormal branches within the central lumen of the organoids when exposed to exogenous BMP-4 (Montesano 2007). This is in contrast to the more commonly seen proepithelial action of BMPs, such as BMP-7, which maintains epithelial differentiation by antagonizing TGF- $\beta$-induced pro-EMT responses of mammary cells (Kowanetz et al. 2004). The latter is also compatible with the prodifferentiating effects of BMP signaling during late stages of mammary duct differentiation (Fig. 1). Alveolar epithelial cells in culture respond to BMPs through activation of the BMPRIA receptor and BMP receptor-activated Smads (R-Smads) that promote terminal alveolar differentiation and expression of milk genes, such as the gene encoding $\beta$-casein (Perotti et al. 2012). In polarized epithelial cells, the BMP receptors segregate onto the basolateral plasma membrane, where they control the expression of epithelial differentiation genes, including genes for tight junction proteins (Saitoh et al. 2013). The role of BMP ligands in the morphogenesis and differentiation of the mammary gland is established, but requires further analyses, especially at the mechanistic level and with the help of transgenic mouse models.

TGF- $\beta$ acts as a suppressor of growth and morphogenesis in the mammary gland (Fig. 1). Its potent inhibitory effect was first shown in vivo using beads that slowly release TGF- $\beta 1$, resulting in arrested development of histologically normal but rudimentary tissue (Silberstein and Daniel 1987). This protocol also showed that the effects of exogenous TGF- $\beta 1$ were reversible on removal of the beads (Silberstein and Daniel 1987) and underscored the developmental plasticity of the mammary gland. Upon weaning, the mammary gland undergoes the highly coordinated tissue remodeling process of involution and returns to a state similar to that of the virgin gland (Macias and Hinck 2012). Using milk-secreting mammary explants from pregnant mice, exogenous TGF- $\beta$ prevents glandular cell differentiation and milk secretion (Robinson et al. 1993). In addition, TGF- $\beta 2$ and TGF- $\beta 3$ expression increases during weaning, but their expression stops and the TGF- $\beta$ levels decline during lactation, suggesting that the TGF- $\beta$ s control the number of lactating mammary cells within the gland (Robinson et al. 1993). The antiproliferative effects of TGF- $\beta$ on mammary epithelial cells have been confirmed in transgenic mice that express activated TGF- $\beta 1$ in the mammary epithelium from a mouse mammary tumor virus (MMTV) promoter (Pierce et al. 1993). These mice show overall reduction in ductal growth, but form, upon pregnancy, hypoplastic but functional alveoli that secrete sufficient milk to feed the newborns (Pierce et al. 1993). However, overexpression of TGF- $\beta 1$ from the Wap promoter (which controls the gene encoding whey acidic protein) during the lactation period when its expression normally declines results in inhibitory effects on mammary gland maturation and lactation (Jhappan et al. 1993). Expressing TGF$\beta 3$ from the Blg promoter (which controls the gene encoding $\beta$-lactoglobulin) showed that TGF- $\beta 3$ locally represses mammary differentiation during involution, by inducing apoptotic loss of the lactating alveoli that must regress upon completion of lactation (Nguyen and Pollard 2000). Intriguingly, the overall pattern of ductal differentiation and outgrowth of mammary gland is normal in Tgfbl-deficient mice, whereas the number of mammary end buds that are fully differentiated decreases (Ingman and Robertson 2008). In addition, transplantation of ductal epithelium from $\mathrm{Tgfb} 1^{-/-}$mutant mice into normal mammary fat pads showed that the mutant epithelium is invasive, revealing a function of TGF- $\beta 1$ in restricting the morphogenetic outgrowth of the gland (Ingman and Robertson 2008). During involution, mammary cells undergoing apoptosis can be cleared through an unusual phagocytic process mediat- 
ed by neighboring nondying mammary epithelial cells; TGF- $\beta 3$ can induce such phagocytic activity in mammary epithelial cells, which contributes to the elimination of the ductal trees (Fornetti et al. 2016). Mammary epithelial phagocytosis coincides with EMT induced by TGF- $\beta 3$ and involves cleavage of E-cadherin from the plasma membrane by intramembranous $\gamma$-secretase and subsequent translocation of $\beta$-catenin from the disassembled adherens junctions into the nucleus (Fornetti et al. 2016).

The antiproliferative actions of the TGF- $\beta$ s in the mammary gland are mediated by the TGF- $\beta$ type II receptor (T $\beta$ RII), and transgenic mice that express a kinase deletion mutant of the T $\beta$ RII receptor in the mammary epithelial cells of developing ducts and alveolar buds, show increased mammary cell proliferation, manifested as tissue hyperplasia, and abnormal milk secretion in virgin females (Gorska et al. 1998). Expression of the truncated T $\beta$ RII in stromal cells of the developing mammary gland results in excessive branching of the ductal epithelium, attesting that TGF- $\beta$ s also limit the morphogenetic potential within the gland (Joseph et al. 1999). These findings have been corroborated by studies of normal or $\mathrm{Tg} f b 1^{+/-}$mice (Nguyen et al. 2011). In the $T g f b 1^{+/-}$Balb/c mouse strain, mature TGF- $\beta 1$ production is significantly reduced in the mammary glands, and morphogenesis of the glandular epithelium is accelerated without any signs of abnormal tissue architecture during all stages of the mammary gland cycle (Nguyen et al. 2011). These findings are again consistent with the role of TGF- $\beta$ as a growth inhibitor. Transplantation experiments using $\mathrm{Tg} f b 1^{+/-}$mammary epithelium grafted into the mammary fat pads of wild-type recipients recapitulates the enhanced ductal outgrowth (Nguyen et al. 2011). However, the inverse transplantation of wild-type mammary explants into the fat pads of $T g f b 1^{+/-}$recipients does not accelerate branching outgrowth, indicating an autonomous regulation of epithelial cell proliferation by TGF- $\beta$ (Nguyen et al. 2011). These experiments confirm that, in the context of the mammary gland, the antiproliferative actions of TGF- $\beta$ are limited to the epithelial cells. A complementary way to characterize the function of T $\beta$ RII in the mammary gland has been through specific inactivation of the Tgfbr 2 gene encoding the T $\beta$ RII receptor in mammary epithelium, which results in hyperplastic alveoli, thus confirming the antiproliferative function of the TRRII in mammary development (Forrester et al. 2005). Interestingly, crossing this mouse with the "oncomouse" that expresses the polyoma virus middle Tantigen from the MMTV promoter results in an enhanced and faster breast cancer metastasis to the lung (Forrester et al. 2005). Immortalized mammary epithelial cell lines have been derived from mice generated by crossing the "immortomouse" that expresses a temperature-sensitive mutant simian virus-40 large T antigen to mice lacking specific Smad genes (Kohn et al. 2010). In these mammary epithelial cells, TGF- $\beta$ induces cell-cycle arrest, apoptosis and EMT through Smad3, but not Smad2, whereas invasive and migratory responses require both Smad2 and Smad3 (Kohn et al. 2010). These findings illustrate the importance of regulating TGF- $\beta$ actions during pregnancy and lactation.

TGF- $\beta$ signaling cross talks with other pathways that drive mammary gland differentiation and lactation, such as prolactin signaling by the Janus kinase (JAK) and the signal transducer and activator of transcription 5 (STAT5) transcriptional regulator (Cocolakis et al. 2008). Prolactin-STAT5 signaling promotes mammary ductal morphogenesis and epithelial proliferation, whereas TGF- $\beta$ signaling has opposite effects (Fig. 1). In addition to TGF- $\beta$, activin A (dimer of the activin- $\beta_{A}$ chain, also known as the inhibin- $\beta_{\mathrm{A}}$ chain) (Namwanje and Brown 2016) can activate Smad2, Smad3, and Smad4 signaling complexes, which interfere with the association of STAT5 and its coactivator CREB-binding protein (CBP) or p300, as Smad proteins form more robust complexes with the same coactivators (Cocolakis et al. 2008). In this manner, activin- and TGF- $\beta$-driven Smad complexes compete for transcriptional activation with STAT5, resulting in inhibition of transcription of STAT5 target genes, including the genes encoding $\beta$-casein and cyclin D1 (Fig. 1). A second mechanism operating during this differentiation process is mediated by the Smad 
K. Kahata et al.

corepressor SnoN (Jahchan et al. 2012). SnoN represses the transcriptional activity of Smad complexes, and TGF- $\beta$ signaling induces the expression of SnoN (Fig. 1). In addition, prolactin induces SnoN expression during late pregnancy in mice, and SnoN promotes STAT5 signaling by stabilizing STAT5 and possibly by neutralizing the antagonistic action of Smads (Jahchan et al. 2012). In agreement with this molecular mechanism, increased STAT5 expression can rescue the defects in alveolar bud differentiation and lactation in SnoN-deficient mice (Jahchan et al. 2012). Another transcriptional cofactor of the nuclear Smad complex is the chromatin-associated protein tripartite motif containing 33 (TRIM33, also known as TIF1 $\gamma$ ), which regulates subsets of TGF- $\beta$-responsive genes (Massagué 2012). Mammary epithelial cell-specific ablation of the Trim33 gene results in normal mammary gland development with a clear lactation defect owing to perturbation in the terminal differentiation of the alveolar epithelium (Hesling et al. 2013). In this model, TRIM33 inhibits the Smad and STAT5 transactivation potential and represses the expression of the prolactin receptor in mammary alveolar cells (Hesling et al. 2013). Thus, the negative effects of TGF- $\beta$ s during the late phase of alveolar differentiation and the onset of lactation involve intimate cross talk with the prolactin-STAT5 pathway, whereas several nuclear coregulators take part in the antagonistic cross talk between these two pathways.

In mammary cancer, EMT has been shown and molecularly analyzed in numerous studies (reviewed in Moustakas and Heldin 2013). Key molecular regulators of the EMT process, such as transcription factors and specific microRNAs (miRNAs) remain to be analyzed in deeper detail in terms of their physiological contributions to mammary gland development outside the context of cancer progression. Mammary EMT is regulated by microenvironmental cues. For example, chronic exposure of mammary epithelial cells to TGF- $\beta$ bypasses the cytostatic and proapoptotic response of these cells, and maintains a long-term mesenchymal (EMT) phenotype with enhanced features of cell invasion (Gal et al. 2008). In addition, the rigidity of the ex- tracellular microenvironment controls the signaling output of TGF- $\beta$, so that low rigidity or stiffness allows cytostatic and proapoptotic responses, whereas high stiffness promotes the EMT responses (Leight et al. 2012). The transcription factor ovo-like zinc finger 2 (OVOL2) is necessary for proper mammary ductal morphogenesis and maintenance of adult stem cells in the mammary gland (Watanabe et al. 2014). OVOL2 represses expression of major EMT transcription factors and thus the potential of TGF- $\beta$ to induce mammary epithelial cell EMT (Watanabe et al. 2014). Depleting OVOL2 from the mammary epithelium inhibits mammary duct development, causes loss of stem cells, and enhances TGF- $\beta$-dependent EMT that perturbs normal differentiation of the gland (Watanabe et al. 2014). The process of MET is often driven by BMPs and has been proposed to preserve mammary epithelial cells from EMT, thus contributing to mammary epithelial differentiation (Moustakas and Heldin 2013).

\section{Prostate Gland}

Androgenic hormones define development of this exocrine organ (Thomson and Marker 2006). The progression of prostatic differentiation depends on paracrine signaling between epithelia and aligned mesenchymal cells in which TGF- $\beta$ family members instruct prostate morphogenesis (Thomson and Marker 2006). The three TGF- $\beta$ s, activin A, BMP-4, and BMP7, inhibit prostatic development, whereas growth and differentiation factor (GDF)-7 promotes growth and branching morphogenesis (Thomson and Marker 2006).

TGF- $\beta 1$ localizes at epithelial-mesenchymal contacts in the prostatic gland of mouse embryos and newborns (Timme et al. 1996). Overexpression of TGF- $\beta 1$ in prostatic epithelial cells results in a hyperplastic response that resembles cancer progression in the gland (Timme et al. 1996). On the other hand, TGF$\beta s$ block prostate gland differentiation by promoting cell-cycle arrest through induction of cyclin-dependent kinase inhibitor $\mathrm{p} 21^{\mathrm{Cip} 1} \mathrm{ex}$ pression, and perturbation of this process by estrogens early after birth results in delayed 
completion of prostate development in rats (Chang et al. 1999). Such variable effects of the TGF- $\beta$ s, like in other epithelial organs, are context-dependent. The growth inhibitory effects may involve immature progenitor cells in the developing buds, whereas TGF- $\beta$ may even stimulate proliferation of differentiated epithelia (Tomlinson et al. 2004), which may explain its protumorigenic action (Timme et al. 1996). The prostate shows morphogenetic gradients of TGF- $\beta$ so that the proximal region that is enriched in stem cells responds with a growth inhibitory response (Salm et al. 2005). The actions of TGF- $\beta$ s on prostatic stem cells leading to their slow proliferation are also maintained by Notch1 signaling that renders the stem cells responsive to TGF- $\beta$ by inducing expression of the TGF- $\beta$ type I receptor (T $\beta$ RI) (Valdez et al. 2012). The TGF- $\beta$ gradient is maintained by regulatory actions of androgens, and changes in androgen abundance can even switch the gradient in an opposite direction (Salm et al. 2005). In agreement with the important roles of epithelial-mesenchymal contacts in prostate epithelial differentiation and morphogenesis, coculture of mouse bladder urothelial tissue with mesenchymal cells of the prostatic primordium (urogenital sinus), induces the generation of prostatic epithelial cells (Li et al. 2009). However, bladder cells lacking T $\beta$ RII owing to tissuespecific gene inactivation remain urothelial and cannot transdifferentiate ( $\mathrm{Li}$ et al. 2009). The mesenchymal cells that express TGF- $\beta$ also activate epithelial Wnt signaling leading to the generation of prostatic epithelial stem cells ( $\mathrm{Li}$ et al. 2009).

Similarly, ex vivo cultures of rat prostatic explants with activin A show a strong block in branching morphogenesis of their developing ducts, whereas the antagonist follistatin promotes branching of the ducts (Cancilla et al. 2001). Normal developing rat prostate glands express activin- $\beta_{A}$ (activin- $\beta_{B}$ appears mainly during puberty), follistatin, and the activin type I and type II receptors (Cancilla et al. 2001).

In addition to TGF- $\beta$, BMP- 4 is highly expressed at epithelial-mesenchymal borders in the developing prostatic gland. BMP-4 may control branching morphogenesis, because mice with only one Bmp4 gene copy show enhanced branching (Lamm et al. 2001). Cultures of prostate epithelial cells in the presence of BMP-4 show inhibition of proliferation and a block in budding capacity (Lamm et al. 2001). BMP-7 may act similarly as BMP-4, and prostate glands from $B m p 7^{-/-}$mice are enlarged with extensive branching (Grishina et al. 2005). In ex vivo prostate organ cultures BMP-7 induces regression of branching buds, which may involve local restriction of Notch1 paracrine signaling (Grishina et al. 2005). The action of BMP ligands can be limited during prostatic gland development by histone deacetylases that repress the expression of the Bmp2 and Bmp4 genes (Keil et al. 2015). As in other epithelia, the extracellular actions of BMPs in the developing prostate are balanced by antagonists, such as noggin. In $\mathrm{Nog}^{-/-}$mice, lacking noggin expression, the ventral region of the prostatic gland regresses by the proapoptotic actions of the BMPs that signal excessively in the absence of the negative regulation exerted by noggin (Cook et al. 2007). BMP signaling in the prostate epithelium is mediated by BMPRIA. Conditional deletion of this receptor in the urogenital sinus epithelial cells blocks cell differentiation, and the prostatic cells lose expression of the transcription factor Nkx3.1, which may promote prostatic epithelial differentiation by BMPs (Omori et al. 2014).

In contrast to the other members of the family, GDF-7 (also known as CDMP-3 or BMP-12) promotes prostate epithelial differentiation (Settle et al. 2001). Further molecular analyses of the mechanism of action of GDF-7 in the prostate remain to be performed.

\section{Pancreatic Organogenesis}

The pancreas is an endoderm-derived organ that consists of three main cell lineages, the exocrine, ductal, and endocrine cells (Kim and Hebrok 2001). These cell lineages originate from the pancreatic bud that is an outgrowth from the foregut, similar to the liver bud (see below) (Kim and Hebrok 2001). The primordial pancreatic cells undergo cycles of EMT and MET during proliferation and morphogenesis, so 
K. Kahata et al.

that primordial epithelial cells generate mesenchymal cells that eventually generate differentiated epithelial and secretory cells (Thomson and Marker 2006). TGF- $\beta$ inhibits epithelial differentiation in the pancreas like in most other glandular organs. Epithelial overexpression of a dominant-negative mutant T $\beta$ RII in transgenic mice results in overt proliferation and abnormal differentiation of pancreatic acini (Böttinger et al. 1997). Thus, TGF- $\beta$ inhibits exocrine pancreatic cell differentiation, whereas enhanced TGF- $\beta 1$ expression leads to organ fibrosis and excessive angiogenesis (Böttinger et al. 1997). Ex vivo cultures of mouse embryonic pancreatic tissue allow one to follow the differentiation of the various cell types and their architectural organization within the developing organoid. Using this methodology, TGF- $\beta 1$ was shown to inhibit differentiation of the acinar compartment of the organoid (Sanvito et al. 1994). Although TGF- $\beta 1$ acts as an inhibitor of differentiation of exocrine pancreatic epithelial cells, it promotes endocrine $\beta$-islet cell differentiation within the organoids cultured ex vivo (Sanvito et al. 1994), which is compatible with the action of TGF- $\beta$ during pancreatic development. However, expression of the dominant-negative T $\beta R I I$ in the pancreatic epithelium suggests that TGF- $\beta$ signaling inhibits endocrine pancreatic differentiation in vivo (Tulachan et al. 2007). A similar inhibition by TGF- $\beta$ signaling is also apparent during aging of the endocrine pancreatic gland (Dhawan et al. 2016). By activating Smad3, TGF- $\beta$ promotes the expression of the cell-cycle regulator $\mathrm{p} 16^{\text {Ink4a }}$, which controls the self-renewal of the adult endocrine stem cells in the pancreas (Dhawan et al. 2016). Under the action of TGF- $\beta$, p $16^{\text {Ink4a }}$ accumulates, prohibiting tissue regeneration as the animals age (Dhawan et al. 2016). Based on this mechanism, pharmacological inhibitors of the T $\beta$ RI kinase help maintain a pool of endocrine $\beta$-cells that can regenerate in older animals (Dhawan et al. 2016).

TGF- $\beta 1$ inhibits ductal epithelial morphogenesis in human pancreatic islet explant cultures embedded in three-dimensional collagen matrices; inversely, anti-TGF- $\beta$ antibody promotes ductal morphogenesis, by neutralizing
TGF- $\beta$ secreted by the pancreatic rudiments (Hanley and Rosenberg 2007). Stimulation of pancreatic duct cells isolated from human donors with TGF- $\beta 1$ induces EMT and transcriptionally represses the expression of $\beta$-cell specific transcription factors, which is compatible with an inhibitory role of TGF- $\beta$ in endocrine cell differentiation and its ability to promote transdifferentiation (Shin et al. 2011). In agreement with the latter observation, human exocrine pancreatic cells undergo EMT when cultured in vitro (Lima et al. 2013). These mesenchymal derivatives can be reprogrammed toward $\alpha$-islet cells following adenoviral expression of endocrine pancreatic transcription factors (Shin et al. 2011). In contrast, $\beta$-islet cells can be generated without transcriptional reprogramming, by using a Rho-associated kinase and a TGF- $\beta$ receptor kinase inhibitor (Lima et al. 2013). Thus, TGF- $\beta$-induced EMTof pancreatic epithelial cells may help generate human pancreatic cells that can then be transplanted to diabetic patients.

Similar to TGF- $\beta$, activin A blocks branching morphogenesis in mouse pancreas explants, while follistatin blocks activin, and thus promotes pancreatic acinar cell differentiation with decreased endocrine $\beta$-cell numbers (Ritvos et al. 1995; Zhang et al. 2004). However, other, yet similar, experiments with pancreatic explants showed that activin A or activin B (activin- $\beta_{B}$ dimer) did not affect pancreatic cell differentiation; instead, activin A caused a transdifferentiation of the embryonic pancreatic tissue to intestinal tissue (van Eyll et al. 2004). Independent transdifferentiation and signaling experiments confirmed that activin A or activin B suppress exocrine $\alpha$-cell differentiation and promote endocrine $\beta$-cell differentiation, enabling insulin secretion (Andrzejewski et al. 2015). The activins repress the expression of $\alpha$-cell transcription factors and induce $\beta$-cell transcription factor expression, and their actions explain the phenotype of mice with a deletion of the Fstl3 gene, encoding follistatin-like 3 , which show hyperplasia of their $\beta$-islets (Andrzejewski et al. 2015). Despite these observations, normal pancreatic tissue expresses activin- $\beta_{A}$ and activin- $\beta_{B}$ in the epithelium, and 
follistatin and activin receptors in the mesenchyme (Ritvos et al. 1995; Maldonado et al. 2000). Activin also regulates endocrine $\beta$-islet differentiation, as transgenic mice overexpressing either a dominant-negative or an activated activin type IB receptor (ActRIB) mutant in their islets show a smaller number of pancreatic islets and a decrease in insulin secretion (Yamaoka et al. 1998). The same approach using a dominant-negative (truncated) activin type II receptor (ActRII) generates abnormal pancreatic tissue with severely altered architecture, small islets and ectopic $\alpha$ and $\beta$ endocrine cells at a distance from the islets, and abnormal exocrine epithelium with atypical acinar morphology (Shiozaki et al. 1999). These observations are supported by ex vivo pancreatic rudiment cultures, in which follistatin controls the relative sizes of differentiated exocrine and endocrine pancreatic tissue (Miralles et al. 1998).

BMP-4 inhibits endocrine pancreatic differentiation and promotes cellular proliferation by inducing the expression of the inhibitor of differentiation 2 (Id2) transcription factor, which binds and inactivates the basic helix-loop-helix transcription factor Neuro-D that drives endocrine islet differentiation (Hua et al. 2006). However, overexpression through electroporation of noggin or dominant-negative BMPRIA in embryonic chicken and mouse pancreas, blocks branching morphogenesis and reduces overall organ size, suggesting a positive role of BMP signaling during pancreatic development (Ahnfelt-Ronne et al. 2010). Similar to the effectiveness of TGF- $\beta$ inhibitors in the generation of $\beta$-islet endocrine cells using human organoid cultures, BMP-7 stimulates the conversion of $\alpha$-exocrine cells toward endocrine $\beta$-cells (Klein et al.2015). This developmental reprogramming may provide a promising approach in regenerative medicine, because such protocols bypass the need of reprogramming by ectopically expressed transcription factors.

Despite the role of TGF- $\beta$ family members in pancreatic tissue differentiation, conditional ablation of Smad4, which encodes the common Smad4 mediator of TGF- $\beta$ /activin- and BMPactivated Smad pathways, in pancreatic epithelial cells did not perturb the normal develop- ment and exocrine or endocrine functions of the pancreas in mice (Bardeesy et al. 2006). Thus, abundant evidence exists for physiological roles of TGF- $\beta$ family members during pancreatic epithelial differentiation, even though contradictory reports generate some ambiguity about the exact role of these ligands and their signaling pathways.

\section{Salivary Gland Formation}

Like in many other glandular organs, ex vivo studies of rudiments have been insightful in studying branching morphogenesis of the salivary gland and have been coupled to developmental studies in mice with targeted gene ablation for defined TGF- $\beta$ family members (Patel et al. 2006).

Immunohistochemical analyses of the parotid and submandibular salivary glands have been performed using human or other mammalian specimens. In human glands, TGF- $\beta 1$ can only be detected at early developmental stages in association with mesenchymal cells, whereas intercalated ductal epithelial cells express TGF- $\beta 2$, and mucous and myoepithelial cells express TGF- $\beta 3$ (Kusafuka et al. 2001; Lourenco et al. 2008). In human fetal and adult salivary glands, the expression of BMP-6 has been immunolocalized only in acinar epithelial cells but not in ductal epithelial cells or mesenchymal stromal cells (Heikinheimo et al. 1999). Similar studies show epithelial localization of BMP-3 in the end buds of developing rat salivary glands with progressive reduction of BMP3 levels as a function of age (Hardy and Kramer 2000).

Similar to its effects in pancreas, activin A blocks salivary morphogenesis, and follistatin blocks the effects of exogenous activin A in salivary gland tissue explants (Ritvos et al. 1995). Conditional overexpression of TGF- $\beta 1$ in salivary epithelial cells of mice results in inhibition of acinar epithelial differentiation and, consequently, lower salivation levels (Hall et al. $2010)$. The increased TGF- $\beta 1$ expression causes accumulation of extracellular matrix that results in local fibrosis and replacement of normal epithelium with pathogenic stromal tissue (Hall 
K. Kahata et al.

et al. 2010). These findings can be reproduced in explanted rudiment cultures impregnated with exogenous TGF- $\beta 1$, which blocks acinar epithelial differentiation and enhances mesenchymal differentiation (Janebodin et al. 2013). Conversely, a low-molecular-weight T $\beta R I$ kinase inhibitor has opposite effects and promotes enlarged growth of the differentiated acinar epithelium (Janebodin et al. 2013).

Thus, TGF- $\beta$ family members are linked to inhibition of epithelial differentiation during salivary gland development; however, more detailed studies are needed to define the pathways and mechanisms that the TGF- $\beta$ s use to guide salivary epithelial morphogenesis.

\section{Thyroid Gland Development}

In cultured thyroid epithelial cells, TGF- $\beta 1$ induces cell-cycle arrest and represses thyroidspecific protein expression and cell differentiation (Colletta et al. 1989). TGF- $\beta 1$ also induces extracellular matrix protein synthesis, as illustrated by its effects on the expression of thrombospondin-1, a phenotype that associates with thyroid epithelial cell migration and morphological adaptation (Claisse et al. 1999). In addition, thyroid epithelial cells undergo EMT when cultured in the presence of epidermal growth factor (EGF) and TGF- $\beta 1$ (Grände et al. 2002). The generation of thyroid cells from embryonic stem cells (ESCs) requires activin A, which promotes differentiation toward the endodermal lineage and initiates the expression of thyroid-specific genes, a process that eventually requires thyroid stimulatory hormone for completion of the differentiation program in culture (Ma et al. 2009).

Conditional expression of TGF- $\beta 1$ in thyrocytes of transgenic NOD mice promotes the development of thyroid hyperplasia, and inhibits autoimmune thyroiditis that is presumably because of enhanced recruitment of regulatory $\mathrm{T}$ cells into the thyroid glands (Yu et al. 2010). BMP signaling promotes thyroid epithelial development, as evidenced from the effects of conditional inactivation of both Smad1 and Smad5 in thyrocytes (Villacorte et al. 2016). The final growth and completion of morphogenesis into organized follicles in the thyroid glands of these mice are defective, resembling the loss-of-function phenotype of the proangiogenic vascular endothelial growth factor-A (Villacorte et al. 2016). Thyroid glands with defective BMP signaling show defective basement membrane, and extracellular matrix proteins like laminins can rescue the developmental defect (Villacorte et al. 2016). Thus, BMP signaling assists in the architectural organization of the epitheliumto-basement membrane barrier (Villacorte et al. 2016). The potential role of TGF- $\beta$ family members in thyroid gland development remains to be better clarified in vivo.

\section{Pituitary Gland Differentiation}

The biology of activins and their major extracellular antagonist follistatin has been historically linked to the function of the pituitary gland and the regulation of gonadotrophin secretion (Bilezikjian et al. 2012). The pituitary gland produces activins and follistatin, and the gonadotropic cells in the gland respond to activin (Bilezikjian et al. 2012). Mice with deletion of the Acvr2 gene encoding ActRII show deficient function of their pituitary gland (Matzuk et al. 1995). The physiological consequence of the loss of ActRII in mice is decreased follicle-stimulating hormone secretion and consequently inefficient maturation of the reproductive cycle (Matzuk et al. 1995). In addition to activin, TGF- $\beta 2$ signaling plays important roles in patterning the pituitary gland, especially its anterior lobe (Tsukada et al. 2016). A special cell type in the gland is the folliculostellate cell, which secretes TGF- $\beta 2$, activating TGF- $\beta$ signaling on adjacent pericytes of the tightly packed pituitary vasculature (Tsukada et al. 2016). This paracrine signaling activates Smads in pericytes and induces the synthesis of normal levels of type I $\alpha 1$ and type III $\alpha 1$ collagens, which are required for adhesion of the endocrine cells in this gland and maturation of the gland (Tsukada et al. 2016). Like in many other instances already discussed, this effect raises the need to define the roles of individual TGF- $\beta$ family proteins (e.g., TGF- $\beta 2$ ) in the normal patterning of the pituitary organ. 


\section{THE TGF- $\beta$ FAMILY IN GASTROINTESTINAL TRACT DEVELOPMENT AND EMT}

\section{Esophageal, Stomach, and Intestinal Differentiation}

Although BMP signaling plays critical roles in gastrointestinal tract development, the TGF- $\beta$ s probably play only homeostatic roles during the continuous shedding and formation of the adult intestinal epithelium (Fig. 2). Early studies of established and primary rat intestinal epithelial cells in culture indicated that the more differentiated intestinal cells at the tip of the villus express high levels of TGF- $\beta 1$, whereas less differentiated cells in the crypt express lower TGF- $\beta 1$ levels (Barnard et al. 1989). The differentiated enterocytes respond potently to TGF- $\beta 1$ and show robust arrest of their cell cycle, suggesting an autocrine role of TGF- $\beta 1$ and a homeostatic function that is important for the balance between proliferating and differentiating cells in the intestinal villus (Barnard et al. 1989). The normal gastric epithelium also undergoes periodic apoptosis in response to TGF- $\beta$ (Ohgushi et al. 2005). TGF- $\beta$ signaling through Smads induces expression of the proapoptotic factor Bim, which acts in the mitochondrial membrane proapoptotic pathway, leading to the release of cytochrome $c$ and the activation of caspase-9 (Fig. 2) (Ohgushi et al. 2005). TGF- $\beta$ induces hypoxia-inducible factor 1 (HIF-1) expression and represses the expression of Id2 during intestinal epithelial apoptosis (Cao et al. 2009). Because Id2 suppresses HIF-1, this activity potentiates the proapoptotic action of HIF-1 (Fig. 2). This TGF- $\beta$-dependent proapoptotic

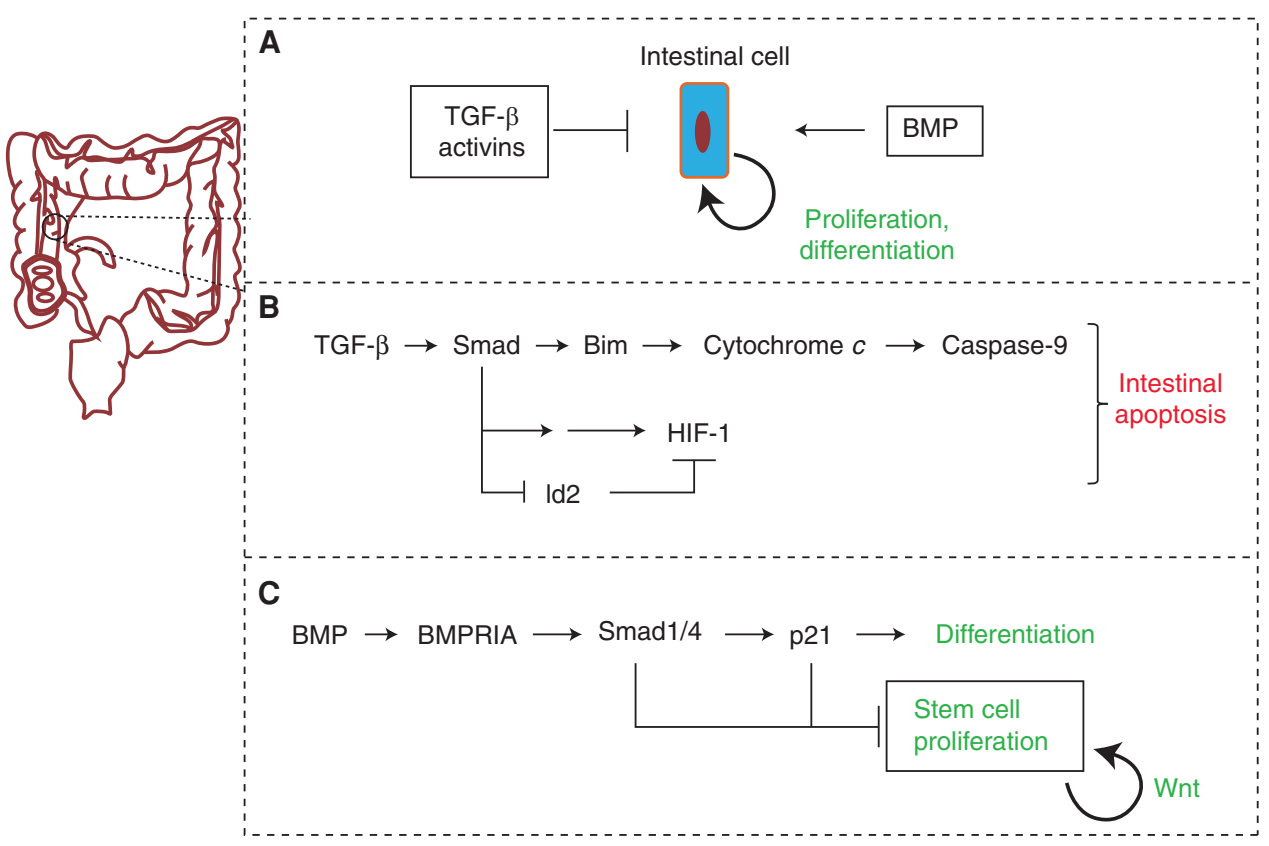

Figure 2. Role of the TGF- $\beta$ family in intestinal development. (A) TGF- $\beta$ s and activins inhibit intestinal epithelial cell proliferation and differentiation, whereas bone morphogenetic proteins (BMPs) promote proliferation and differentiation. (B) TGF- $\beta$ induces intestinal epithelial cell apoptosis by activating Smads, which induce expression of the proapoptotic protein Bim, leading to cytochrome $c$ release from mitochondria and caspase- 9 proteolytic activity. TGF- $\beta$-activated Smad signaling can also promote expression of the hypoxiainducible factor 1 (HIF-1) and repress expression of the HIF-1 inhibitor Id2, resulting in apoptotic signaling in the intestinal cells. $(C)$ BMPs activate BMPRIA, which promotes differentiation of intestinal stem cells through Smad1 activation and transcriptional induction of the cyclin-dependent kinase inhibitor p21 ${ }^{\mathrm{Cip} 1}$. Smad1 and p $21^{\mathrm{Cip} 1}$ inhibit stem cell proliferation, whereas Wnt signaling promotes stem cell proliferation in the intestinal epithelium. 
K. Kahata et al.

pathway may be induced in the intestine by dietary fibers, which can thus act in a protective manner against the generation of hyperplasia in the gut (Cao et al. 2009). These cell culture studies have been recapitulated in vivo with TGF- $\beta 1$ administration to the gastrointestinal tract of fasting rats (de Andrade Sa et al. 2008). The gastric epithelial cells show enhanced cell-cycle arrest and apoptosis in response to the exogenous TGF- $\beta$. This experiment relates to the physiological exposure of the newborn mammalian gastrointestinal tract to TGF- $\beta$ that is enriched in and delivered though the milk of the mother (de Andrade Sa et al. 2008).

The activins also play a prominent role in regulating proliferation and maintenance of stem cells of the gastric epithelium. Normal gastric epithelial morphogenesis is not perturbed when the genes encoding activin- $\beta_{A}$, activin$\beta_{\mathrm{B}}$, or ActRII are inactivated in mice (Li et al. 1998). However, activin signaling through ActRII represses the differentiation of specific subpopulations of gastric cells, such as the parietal cells that control the acidity of the stomach during digestion, zymogenic cells that produce pepsinogen and pit cells that secrete mucus (Li et al. 1998). Cell culture studies also show complex roles of activin signaling in intestinal epithelial cells. Depending on the cellular origin, activin A induces cytostasis in primary embryonic rat epithelial cells of the stomach, whereas it induces proliferation of primary colonic epithelial cells (Fukamachi et al. 2013). The in vivo relevance of this difference remains to be examined.

On the other hand, BMPs produced by the underlying mesenchyme promote gastric epithelial differentiation, for example, in chicken embryos (Narita et al. 2000). Increased BMP-2 activity promotes formation of large numbers of glands, whereas delivery of noggin to the developing gut blocks glandular formation (Narita et al. 2000). BMPs also define the differentiation of the epithelium that forms the pyloric sphincter, which separates the gastric mill (gizzard) from the duodenum (Moniot et al. 2004). In the sphincter, BMPs act on mesodermal cells and induce the expression of the homeobox transcription factors Sox 9 and Nkx2.5 (Moniot et al. 2004). Sox9 induces ex- pression of Gremlin, which neutralizes the action of BMPs in the adjacent endoderm, leading to epithelial differentiation and formation of the sphincter epithelium (Moniot et al. 2004).

The gastrointestinal tract is innervated by nerve cells derived from progenitors of the neural crest; ablation of these progenitors causes mesenchymal cells to increase the secretion of BMPs and to express the Notch receptor, coordinately contributing to the generation of smooth muscle cells (Faure et al. 2015). This defect is also accompanied by transdifferentiation of the adjacent stomach epithelium into a gastrointestinal epithelium of mixed identity (gastric and colonic) (Faure et al. 2015). Thus, proper compartmentalization of the gastrointestinal tract is controlled by the action of enteric neural crest cells, whose ultimate role is to generate the intestinal nervous system.

In agreement with chicken gastrointestinal development, mice lacking noggin show major defects in esophageal formation because excessive BMP signaling disrupts the communication of the endoderm with the notochord (Que et al. 2006). Accordingly, hemizygosity for Bmp4 can partially rescue the defects of $\mathrm{Nog}^{-/-}$mice (Que et al. 2006). Differentiation of esophageal epithelial cells from the adjacent endodermal progenitor cells also requires BMP signaling through generation of reactive oxygen species, which block the ubiquitin-mediated degradation of nuclear factor-erythroid-2-related factor 2 (Nrf2), causing Nrf2 stabilization (Jiang et al. 2015). Stabilized Nrf2 then transcriptionally controls the differentiation of the squamous esophageal epithelium (Jiang et al. 2015). BMPregulated Nrf2 controls a homeostatic balance, which, when perturbed by inflammatory conditions, leads to epithelial hyperplasia and esophagitis (Jiang et al. 2015). In contrast to the negative effects of activins on parietal cell differentiation in the stomach, parietal cell-specific overexpression of noggin leads to elimination of these cells, suggesting that physiological BMP signaling is required for parietal cell differentiation (Shinohara et al. 2010). Thus, activins and BMPs may antagonize each other during the specification of this specific epithelial cell type in the stomach (Fig. 2). Furthermore, the effect of 
noggin overexpression in the gastric cell-specific transgenic mouse is significantly compromised or reverted after subsequent ablation of the gene encoding gastrin (Todisco et al. 2015). This result indicates that increased noggin expression in the parietal cells leads to gastrin secretion, which then drives proliferation of the gastric epithelial cells and loss of the parietal cells. A similar effect of noggin overexpression is apparent when the Bmprla gene is inactivated in the endoderm during early gut development (Maloum et al. 2011). These mice do not show defects in differentiation or proliferation of their gastric gland cells, but the pattern of development is abnormal and specific differentiated cell types, like parietal cells, are lost in the absence of BMP signaling in the foregut endoderm (Maloum et al. 2011). In addition, gastric endocrine cells increase in numbers, suggesting that BMPRIA limits their proliferation (Maloum et al. 2011). The overall role of BMP signaling in the differentiation of the gastric epithelium is also emphasized by the use of noggin as one of the essential ingredients in the growth factor cocktail that drives the in vitro generation and differentiation of mini-stomach organoids from mouse ESCs (Noguchi et al. 2015). Similarly, BMPs in this cocktail induce differentiation of human pluripotent stem cells into three-dimensional mini-stomachs (McCracken et al. 2014).

A different view of the role of BMPs in the intestinal epithelium has been derived from transgenic mouse studies. Similar to the gastric tract of the chick, BMP-4 is highly expressed in the mesenchyme of the intestinal villi and restricts the proliferation of intestinal epithelial cells (Fig. 2) (Haramis et al. 2004). Thus, transgenic mice with a villus-specific expression of noggin develop increased numbers of ectopic crypts (Haramis et al. 2004). This phenotype is in agreement with the effects of loss-of-function mutations of the BMPRIA or the SMAD4 genes in patients with juvenile polyposis, who also develop benign hyperplastic villi known as hamartomas (Fig. 2). In agreement with these findings, inactivation of Bmprla in intestinal stem cells causes polyposis because of increased proliferation of the stem and progenitor cell compartment of the intestinal crypt ( $\mathrm{He}$ et al.
2004). As Wnt signaling controls the proliferation and maintenance of the intestinal crypt stem cells, BMP signaling counteracts the Wnt pathway and thus limits the proliferative potential of these stem and progenitor cells (Fig. 2). An independent study of intestinal epithelial cell-specific Bmprla inactivation shows that BMP signaling is required for the terminal differentiation of intestinal secretory cells (Auclair et al. 2007). However, the apparent absence of polyposis and effects on intestinal crypt stem cells, observed in this model, suggest that the impact of BMP signaling on the intestinal crypt depends on the abundance of BMP receptors in the mesenchyme associated with the villi $(\mathrm{Au}-$ clair et al. 2007).

The characteristic clustering of intestinal epithelial cells in villi that mediate nutrient absorption is regulated by the balance of extracellular BMP antagonists secreted by mesenchymal cells and BMP receptor signaling in both mesenchymal and intestinal epithelial cells (Walton et al. 2016). Perturbation of this balance, as achieved by the deletion of the Bmprla gene, leads to longitudinal stripes of villified epithelium (Walton et al. 2016). Tissue patterning simulations show that the normal pattern of villified intestinal epithelium requires balanced BMP signaling along the entire surface of the mouse intestine, which generates a system that is able to self-regulate or self-sustain in a pattern of so-called Turing fields (Walton et al. 2016). In three-dimensional cultures of human colonic epithelium, the maintenance of stem cells and progenitor cells depends on Wnt signaling, whereas TGF- $\beta$ (possibly activin) and BMP signaling limit stem cell maintenance in the organoids (Walton et al. 2016). Such studies using human tissue-derived models will be important to evaluate the detailed roles of TGF- $\beta$ family signaling in the homeostasis and differentiation of the gastrointestinal tract.

\section{THE TGF- $\beta$ FAMILY IN LIVER AND BILE DUCT ORGANOGENESIS AND EMT}

The liver bud, which gives rise to the adult liver, is derived from a ventral appendix of the foregut-that is, the diverticulum (Tremblay 2011). 
K. Kahata et al.

Hepatoblasts in the liver bud are of epithelial origin and the bud is surrounded by an extracellular basement membrane that contacts the basal plasma membrane of the hepatoblasts. Hepatoblast proliferation generates a pseudostratified epithelium at the tip of the liver bud, whose front cells breach through the basement membrane and locally delaminate from the lower bud epithelium through an EMT process (Nieto 2009). These mesenchymal hepatoblasts then aggregate around the portal vein and differentiate into biliary epithelial cells and hepatocytes through processes that resemble MET.

Early studies of rat liver epithelial cell differentiation revealed TGF- $\beta 1$ expression in nonparenchymal cells and early progenitor stages of the oval cells before terminal differentiation (Nagy et al. 1989). In culture, the rat liver epithelial cells show signs of early stages of differentiation toward hepatocytes in response to TGF- $\beta 1$ (Nagy et al. 1989). On the other hand, hepatocytes often respond to TGF- $\beta 1$ by undergoing apoptosis, which requires Smad activation and the activating protein 1 (AP-1) transcriptional complex (Fig. 3) (Schuster and Krieglstein 2002). In embryonic hepatocytes, the apoptotic response to TGF- $\beta 1$ depends on their stage of differentiation (Sanchez et al. 1999). Thus, hepatocytes that express differentiation genes, such as the transcription factors hepatocyte nuclear factor $1 \alpha$ (HNF1 $\alpha$ ) and HNF4, show a robust apoptotic response to TGF- $\beta 1$,

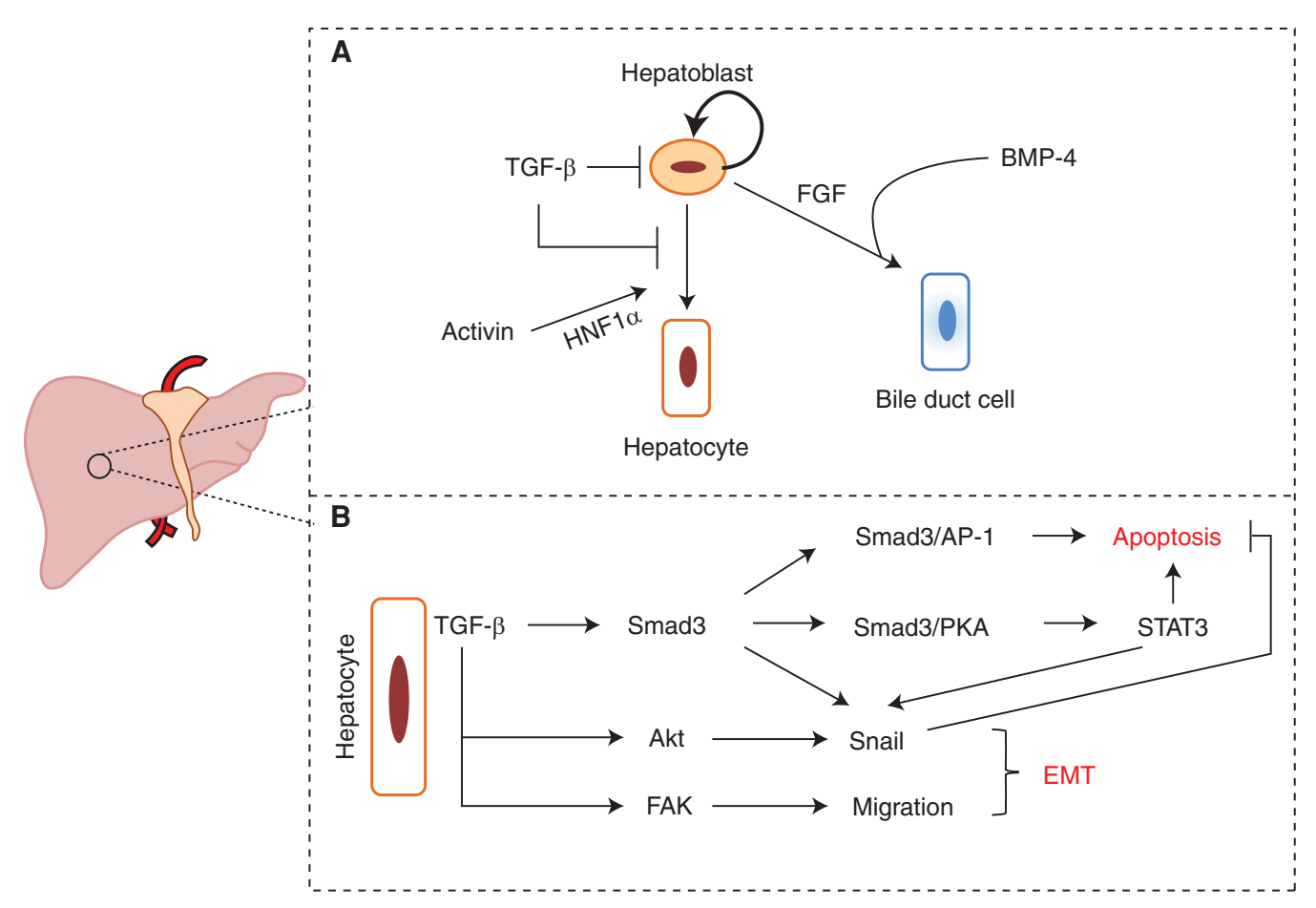

Figure 3. Role of the TGF- $\beta$ family in liver organogenesis. (A) TGF- $\beta$ inhibits self-renewal of hepatoblasts and differentiation of hepatoblasts to hepatocytes. Activins induce hepatoblast differentiation into hepatocytes through transcription factor hepatocyte nuclear factor $1 \alpha$ (HNF1 $\alpha)$. BMP-4, along with FGF signaling, induces hepatoblast differentiation into bile duct cells. (B) In differentiated hepatocytes, TGF- $\beta$ acts as a proapoptotic factor through activation of Smad3 and protein 1 (AP-1), Smad3 and protein kinase A (PKA), and STAT3 signaling. TGF- $\beta$ also induces epithelial-mesenchymal transition (EMT) through transcriptional induction of Snail. Both Smad3 and STAT3 promote Snail expression, and Akt signaling contributes to Snail stabilization. EMT correlates with liver cell migration for which focal adhesion kinase (FAK) activation downstream from TGF- $\beta$ is important. 
whereas those that do not express liver-specific genes lack an apoptotic response and transition through EMT (Fig. 3) (Sanchez et al. 1999). The resistance to apoptosis is mediated by the transcription factor Snail, which is induced by Smad proteins and correlates with high levels of Akt kinase, a hallmark of EMT (Fig. 3) (Valdés et al. 2002; Kaimori et al. 2007). Thus, misexpression of Snail in the liver can modulate responsiveness to TGF- $\beta$ by blocking apoptotic and promoting EMT responses (Franco et al. 2010). The TGF- $\beta$-Akt signaling pathway involves the membrane protein caveolin- 1 , which partitions in cholesterol-enriched plasma membrane domains (Meyer et al. 2013). Silencing of caveolin1 expression using RNAi in cultured hepatocytes results in enhanced apoptotic response to TGF$\beta$ (Meyer et al. 2013).

Analyzing mechanisms that mediate hepatocyte apoptosis versus EMT in response to TGF- $\beta$ revealed the requirement of a common pathway for these two responses involving protein kinase A (PKA) and its transcriptional mediator STAT3 (Yang et al. 2006). TGF- $\beta$-activated Smad3 directly binds and regulates the activity of PKA, and STAT3 activation promotes induction of proapoptotic and pro-EMT genes (Fig. 3) (Yang et al. 2006). This mechanism suggests that during EMT, mediators such as Snail, secondarily impose a prosurvival state in hepatocytes. In addition to EMT-like responses, chronic exposure of rat fetal hepatocytes to TGF- $\beta$ causes a stem cell-like phenotype characterized by repression of hepatic differentiation factors (e.g., HNF1 $\beta$, HNF4), maintenance of HNF3 $\beta$ expression and expression of liver detoxifying enzymes (del Castillo et al. 2008; Caja et al. 2011). In culture, these stem-like hepatic cells can differentiate into hepatoblasts and biliary cells or hepatocytes, using defined differentiation cocktails (del Castillo et al. 2008; Caja et al. 2011). In agreement with these studies, primary mouse liver precursor cultures in three-dimensional organoids reveal bipotential differentiation whereby the progenitor-like cells can differentiate into cholangiocytes or hepatocytes, and TGF- $\beta$ stimulation blocks differentiation to maintain the more progenitor-like features of the organoid culture (Akkari et al.2010).
Hepatocyte EMT also depends on activation of the tyrosine kinase Src and its effector, focal adhesion kinase (FAK), whose action is mainly directed toward the regulation of proinvasive genes that drive the motility of hepatocytes (Cicchini et al. 2008). Immortalized differentiated hepatocytes show biphasic motility patterns that are characterized by hepatocyte adhesion to matrix fibronectin through integrins, thus promoting collective cell migration, followed by waves of cell detachment from the fibronectin-enriched extracellular matrix, resulting in random migration (Biname et al. 2008). It will be important to understand why continuous exposure to TGF- $\beta$ causes oscillatory patterns of protein expression and cell behavior.

Hepatocyte-specific Tgfbr2 deletion mediated by the Cre recombinase expressed from the Alb promoter explains the role of TGF- $\beta s$ in liver regeneration after partial hepatectomy (Romero-Gallo et al. 2005). Although normal liver regenerates to its original size after hepatectomy, Tgfbr2-deficient mice show overgrowth of the regenerating liver, which is compatible with the antiproliferative and proapoptotic actions of TGF- $\beta$ (Romero-Gallo et al. 2005). The Tgfbr2 $2^{-/-}$hepatocytes that are resistant to TGF- $\beta$ show increased phosphorylation of the p130-E2F4 transcription complexes, resulting in enhanced cyclin E expression, thus causing excessive hepatocyte proliferation (Romero-Gallo et al. 2005). Similar Alb-Cre-driven inactivation of $S m a d 2$ or Smad 3 in the liver illustrates the differential roles of these two Smad proteins that are activated by TGF- $\beta$ family members (Ju et al. 2006). The liver-specific deletion of Smad2, Smad3, or both does not perturb normal liver development (Ju et al. 2006). However, when the mice are challenged with carbon tetrachloride that causes liver damage and fibrosis, the hepatocytes that lack Smad2 show a dramatically enhanced rate of proliferation, unlike the Smad3-deficient hepatocytes that show a wildtype response (Ju et al. 2006). Inversely, primary hepatocytes derived from these mice in culture show that liver cytostasis and EMT require Smad3, whereas Smad2 is dispensable for these responses (Ju et al. 2006). In fact, the Smad2-deficient hepatocytes show "spontane- 
K. Kahata et al.

ous" EMT, compatible with hypersensitivity to autocrine or serum-derived TGF- $\beta$ (Ju et al. 2006). Overall, this study established that Smad3 mediates the antiproliferative, apoptotic, and EMT responses in liver cells, whereas Smad2 provides a balancing signal that may even counteract some Smad3 activities.

Activin A signaling in early Xenopus laevis embryos induces expression of the transcription factor HNF1 $\alpha$ (Fig. 3), which promotes progenitor cell differentiation to liver, gut, kidney and gall bladder (Weber et al. 1996). This transcriptional induction may be mediated by Smad complexes in cooperation with HNF4, another transcription factor with which the Smads interact directly (Chou et al. 2003); however, the exact transcriptional mechanism remains to be elucidated. Overexpression of activin C (activin- $\beta_{C}$ dimer) in transgenic mice affects the function of several organs including the liver, which develops larger than normal because of excessive hepatocyte proliferation and suppression of apoptosis (Gold et al. 2009). Activin C has been proposed to antagonize activin $\mathrm{A}$, but its function may also counteract the effects of TGF- $\beta$ during liver development. The inhibitory Smad7 is known to repress signaling by TGF$\beta$ and activin receptors, although it can also block BMP signaling (Miyazawa and Miyazono 2016). Hepatocyte-specific ablation of Smad7 using the $A l b$-Cre system mimics enhanced TGF- $\beta$ /activin-induced Smad activation (Zhu et al. 2011). Furthermore, although many Smad $7^{-/-}$mice are viable and develop a normal liver, a small proportion of animals show liver disease coupled to loss of total body weight and signs of hepatic damage characterized by increased plasma levels of amino-transferases (Zhu et al. 2011). The observed liver damage may be explained by enhanced hepatocyte apoptosis, which is compatible with enhanced TGF- $\beta$ signaling, whereas pathological injury of the liver after alcohol consumption is exacerbated in the Smad7 ${ }^{-/-}$mice (Zhu et al. 2011). The variation in extent of the liver-specific phenotypes in these mice depends on the efficiency of deletion of the Smad7 gene, which apparently fails to be inactivated in a large proportion of animals (Zhu et al. 2011), suggesting that the genetic deletion may be counterbalanced by the action of unknown "modifier" genes. This experiment suggests that limiting the activity of activin and TGF- $\beta$ signaling in the liver may be required for normal liver development, a conclusion that awaits a more robust inactivation of hepatic Smad7 gene expression in mice.

In addition to hepatocytes, liver progenitor cells, such as hepatoblasts, can differentiate into bile duct cells, which are also of epithelial character. Using explanted hepatic bud cultures, BMP-4 was found to potentiate bile duct epithelial differentiation promoted by fibroblast growth factor 2 (FGF2, also known as basic FGF) (Fig. 3) (Yanai et al. 2008). The liver also expresses and secretes BMP-9, which regulates endothelial cell proliferation and monolayer integrity (Suzuki et al. 2010; Bidart et al. 2012; Long et al. 2015). The liver secretes both an inactive and an active form of BMP-9 that enter the circulation and act in a hormonal manner on the endothelial cells of the vasculature ( $\mathrm{Su}$ zuki et al. 2010; Bidart et al. 2012; Long et al. 2015). This observation suggests that the health of the liver during adult life regulates the homeostasis of the vasculature. In addition, BMP signaling, mediated by GPI-anchored coreceptors of the repulsive guidance molecule (RGM) family, regulates normal iron homeostasis in the liver (Babitt et al. 2006). The RGM protein RGMc, also known as hemojuvelin, assists BMP-6 in binding to its receptors and translationally enhances the expression of hepcidin, a homeostatic regulator of intracellular iron stores (Babitt et al. 2006). Activin B also binds to RGMc in the liver, mediating signaling through ActRII and ActRIIB and the type I receptors BMPRIA and ActRI, which activate Smad5 and enhance hepcidin expression (Canali et al. 2016). Chemical inhibitors of the BMPRIA kinase can control liver regeneration after injury, providing a promising development toward therapy of organ failure (Tsugawa et al. 2014).

\section{THE TGF- $\beta$ FAMILY IN KIDNEY AND BLADDER ORGANOGENESIS AND EMT}

Kidney is a mesoderm-derived organ. The ureteric bud is formed from the intermediate me- 
soderm through an MET process early in development and forms the differentiated epithelial tissue (Reidy and Rosenblum 2009). The ureteric bud at the posterior part of the nephric duct grows into the surrounding metanephric mesenchyme and completes branching morphogenesis (Reidy and Rosenblum 2009). The metanephric mesenchyme cells organize themselves around branching ureteric buds, collapse into aggregates, and epithelialize to form renal vesicles through MET (Reidy and Rosenblum 2009). These vesicles are surrounded by a basement membrane, have an apical lumen and undergo further tubular morphogenesis to give rise to renal tubules and the nonvascular part of the renal glomeruli (Reidy and Rosenblum 2009).

The BMPs play key roles in patterning the kidney and guiding morphogenesis from the mesenchyme toward glomerular epithelial differentiation (Fig. 4) (Godin et al. 1999). $B m p 7^{-/-}$mice show loss of the kidney glomerulus, placing BMP-7 as an important differentiation factor in kidney organogenesis (Fig. 4A,E) (Karsenty et al. 1996). Bmp $4^{+/-}$mice show reduced kidney size and abnormal development of the urinary tract (Miyazaki et al. 2000). This happens because BMP-4 limits the extent of nephric budding along the Wolffian tube and promotes branching morphogenesis of the developing ureter (Miyazaki et al. 2000). BMP-4 that is produced by the ectodermal cells induces further BMP-4 expression and secretion by mesodermal cells, which drives nephric mesoderm morphogenesis and subsequent differentiation of the nephric duct (Fig. 4D) (Obara-Ishihara et al. 1999). Delivery of recombinant BMP-4coated beads to embryonic explants can fully replace the experimentally removed ectodermal tissue, confirming that BMPs are critical for the interaction between the ectoderm and mesoderm, so that nephric bud morphogenesis can be initiated (Obara-Ishihara et al. 1999). In embryonic kidney explants, BMP-2 and, unexpectedly, BMP-4 inhibit tubular growth and branching morphogenesis, whereas BMP-7 has the same effect only at high local doses, at low doses promoting branching morphogenesis (Piscione et al. 1997; Raatikainen-Ahokas et al. 2000).
Additionally, inactivation of expression of the BMP antagonist Gremlin, encoded by the Grem1 gene, leads to abnormal kidney development at early stages before branching morphogenesis, with the nuclei of the mesenchyme of these Grem1 $1^{-/-}$mice showing enhanced Smad1 activation (Michos et al. 2007). The Grem $1^{-/-}$phenotype could be rescued by exposure of explanted ureteric buds to recombinant Gremlin or by genetic reduction of the Bmp4 gene copy number in a compound transgenic animal (Michos et al. 2007). The compensation from reducing endogenous BMP-4 expression suggests that BMP signaling is tightly controlled during the initiation of nephric bud outgrowth and morphogenesis, and that Gremlin titers down the BMP activity to allow proper developmental potential in the kidney (Fig. 4D). Similar experiments in which the Grem1 deletion was coupled to $B m p 7$ inactivation showed that loss of one Bmp7 allele was not sufficient to rescue abnormal kidney development, whereas inactivation of both $B m p 7$ copies could restore the ureteric bud morphogenetic pattern (Fig. 4E) (Goncalves and Zeller 2011). However, this rescue in branching morphogenesis does not result in normal kidneys, and organ dysplasia still prevails to an extent that resembles the $B m p 7^{-7-}$ phenotype (Karsenty et al. 1996). Thus, the effect of Gremlin as a BMP antagonist is more global, in the sense that it antagonizes BMP-7, BMP-4, and possibly other BMP activities during kidney development.

Increased expression or ablation of the extracellular BMP antagonist Cerberus- 1 in the ureteric bud of mice leads to a phenotype of enlarged kidneys (Chi et al. 2011). This defect results from altered branching morphogenesis that correlates with increased levels of glial cell-derived neurotrophic factor (GDNF) and Wnt11, which are known to mediate the branching process in the ureteric buds (Fig. 4D) (Chi et al. 2011). Transcriptomic studies in kidney epithelial cells treated with TGF- $\beta 1$ identified Wnt11 as a target gene, promoting signaling through a noncanonical Wnt pathway that involves activation of the c-Jun amino-terminal kinase (JNK) and activation of expression of the EMT transcription factors Snail and 
K. Kahata et al.

A

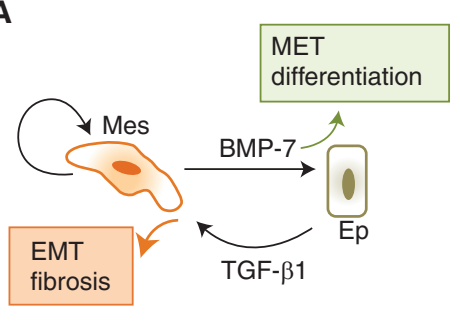

C

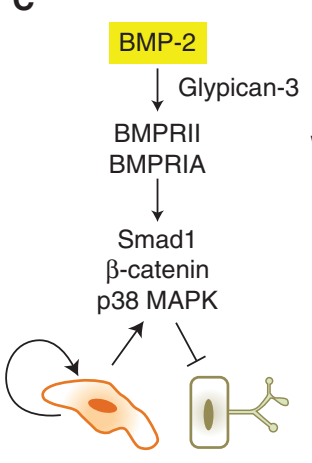

D

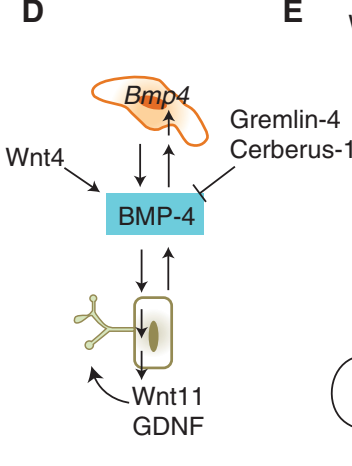

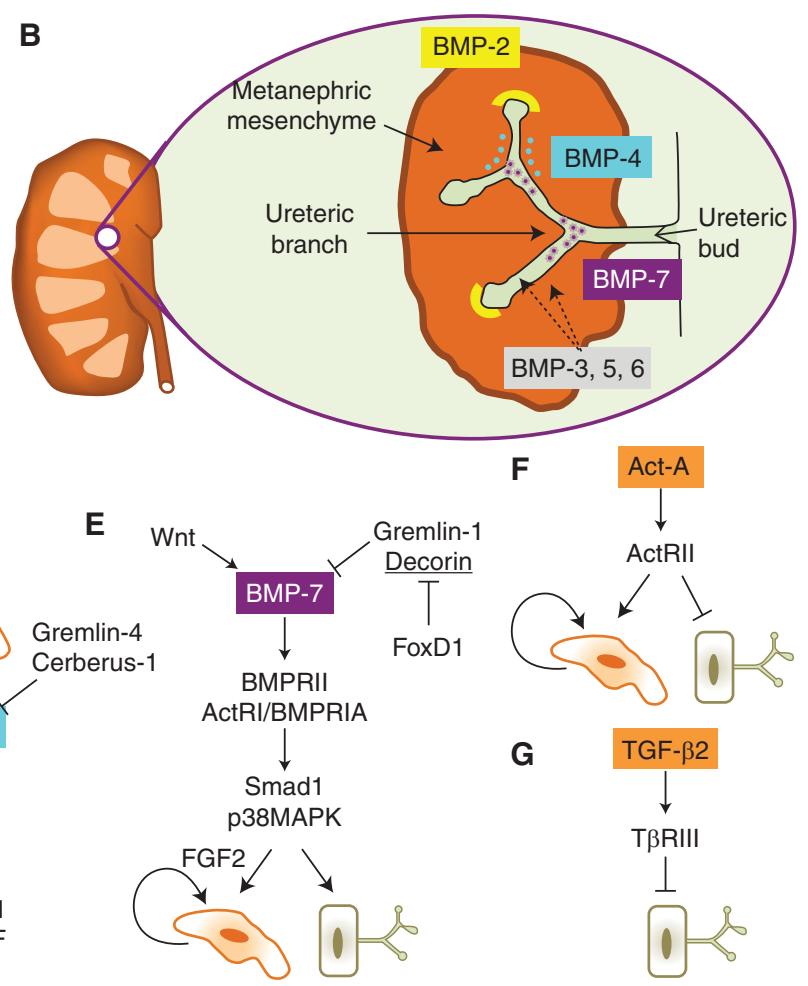

Figure 4. Role of the TGF- $\beta$ family in kidney organogenesis. (A) Overall logic of bone morphogenetic protein (BMP) and TGF- $\beta$ signaling effects in the kidney. A metanephric mesenchymal cell (Mes) is shown to differentiate into an epithelial cell (Ep) of the branching ureteric bud. BMP-7 promotes differentiation and causes MET. Mesenchymal cells proliferate (self-targeting arrow). Under pathologic conditions TGF- $\beta 1$ induces EMT, promotes the mesenchymal phenotype, and tissue fibrosis. (B) A snapshot of early steps during branching morphogenesis in the kidney. A developed kidney on the left and a primitive ureteric bud with its developing branches and the surrounding metanephric mesenchyme. Localization of BMP ligands is shown in the mesenchyme (orange) or lumen of the developing ureteric epithelium (green). Three BMPs, BMP-2 (yellow cup), BMP-4 (blue dots), and BMP-7 (purple stars), are highlighted because they are extensively discussed in this review. BMP-3, -5 , and -6 are also expressed either in the mesenchyme or the epithelium (dotted arrows) but they are not discussed in this review because of the lack of substantial functional analyses in the kidney. $(C)$ BMP-2 signaling inhibits branching morphogenesis and promotes mesenchymal proliferation. The coreceptor glypican-3 assists BMP-2 signaling through BMPRII and BMPRIA, which activate Smad1, $\beta$-catenin, and p38 mitogen activated protein kinase (MAPK) in the epithelial cells. $(D)$ BMP-4 signaling promotes branching morphogenesis. BMP-4 is expressed through epithelial ectodermal cells and acts on mesenchymal cells, which then secrete their own BMP-4 (shown as the Bmp4 gene in the cell nucleus) that acts on the epithelial cells and promotes branching of the growing epithelium through transcriptional induction and secretion of Wnt11 and glial cell-derived neurotrophic factor (GDNF). Wnt4 is an upstream inducer of BMP-4 expression, whereas the extracellular antagonists Gremlin-4 and Cerberus-1 limit the activity of BMP-4. (E) BMP-7 signaling promotes branching morphogenesis and mesenchymal proliferation. Wnt signaling transcriptionally induces BMP-7 expression, whereas the extracellular antagonists Gremlin-1 and Decorin limit the activity of BMP-7. Decorin (underlined), but not Gremlin-1, expression is transcriptionally repressed by FoxD1. BMP-7 signals through BMPRII, ActRI and BMPRIA, which activate Smad1 and p38 MAPK signaling, to promote branching of the growing epithelium or mesenchymal proliferation. $(F)$ Activin A inhibits branching morphogenesis and promotes mesenchymal cell proliferation. Activin A signaling through activin type II receptor (ActRII) inhibits branching of the growing epithelium and promotes mesenchymal proliferation. ( $G$ ) TGF- $\beta 2$ inhibits branching morphogenesis. TGF- $\beta 2$ signaling by the coreceptor T $\beta$ RIII/ betaglycan and the receptors T $\beta$ RII and T $\beta R I$ (not shown) inhibits branching of the growing epithelium. 
ZEB1, of $\alpha$-smooth muscle actin ( $\alpha$-SMA), and of extracellular plasminogen activator inhibitor 1 (Zhang et al. 2012). These confer a characteristic EMT response of epithelial cells that correlates with a fibrotic phenotype in an in vivo model of ureteral obstruction (Zhang et al. 2012). Thus, Wnt11 may play important roles in kidney morphogenesis downstream from both BMP and TGF- $\beta$ ligands. The extracellular proteoglycan decorin can antagonize BMP-7 during the establishment of nephric progenitor cell competence to signals from the adjacent epithelium (Fetting et al. 2014). The forkhead transcription factor FoxD1 represses decorin expression (Fig. 4E), which is required for the differentiation of the nephron in the interstitial space that lines the niche of nephron progenitors (Fetting et al. 2014). Foxd1 $1^{-/-}$mice show abnormal differentiation of their interstitial cells, because decorin expression is derepressed and capable of neutralizing BMP-7 signaling (Fetting et al. 2014).

Studies using Bmp7-LacZ reporter mice, in which the reporter reflects the $B m p 7$ expression pattern, defined $B m p 7$ expression in the kidney epithelium, which is controlled by Wnt (Fig. 4E) and associated extracellular matrix proteoglycans (Godin et al. 1998). The dose-dependent action of BMP-7 described above may explain the inhibition of mesenchymal apoptosis by BMP-7 in the developing nephron, whereas coordinate signaling by FGF2 and BMP-7 can promote growth and maintenance of mesenchymal progenitor cells (Fig. 4E) that generate the stromal compartment in the developing kidney (Dudley et al. 1999). A key proteoglycan that mediates the FGF2-BMP-7 cross talk in the developing kidney is glypican-3, whose gene deletion in the mouse leads to regression of the collecting ducts (Grisaru et al. 2001). Glypican-3 is required for the control of nephric branching morphogenesis, as negative regulation of morphogenetic budding by BMP-2 depends on glypican-3 (Fig. 4C), and BMP-7 stimulates morphogenesis in the absence of glypican-3 (Grisaru et al. 2001). In addition, Wnt 4 can act on the smooth muscle cells in the kidney medulla, where Wnt4 localization correlates with induced expression of BMP-4
(Fig. 4D), which then promotes differentiation of the smooth muscle cells (Itäranta et al. 2006).

The receptors BMPRII, BMPRIA, and BMPRIB are coexpressed in the developing kidney, primarily at the tips of the developing ureter and the associated mesenchyme, as defined by in situ hybridization (Martinez et al. 2001). Mice expressing a constitutively active BMPRIA show severe abnormalities in kidney development, with the most severe case being cystic dysplasia of the medulla, resembling disease in children that leads to renal failure ( $\mathrm{Hu}$ et al. 2003). The active BMPRIA induces nuclear complexes of Smad 1 and $\beta$-catenin, causing inhibition of branching processes, overgrowth of the mesenchyme, and generation of cysts in the place of normal collecting ducts ( $\mathrm{Hu}$ et al. 2003). Inversely, Bmprla gene deletion in the mouse primitive uretery bud leads to excessive branching of the buds, which later regress, leading to an overall decrease in the medulla of the kidney and severe loss of mature collecting ducts (Hartwig et al. 2008). In addition to the activities of Smad $1-\beta$-catenin complexes, renal cell cultures and ex vivo organ cultures show cooperation of the p38 mitogen activated protein kinase (MAPK) with Smad1 in some responses (Fig. 4C,E) (Hu et al. 2004). Reporter mice that express $\beta$-galactosidase from a BMPresponsive $I d 1$ gene promoter have been used to address the roles of Smad signaling downstream from BMPs in vivo (Blank et al. 2008). Although the full spectrum of BMP-dependent signaling activities in vivo may not be captured by the Id 1 promoter, strong BMP signaling activity localizes to the main ductal tube, but not the tips of the collecting ducts, and weak activity localizes to the nephrogenic progenitor cell area of the developing organ (Blank et al. 2008). This is in contrast to the localization of BMP receptor expression using in situ hybridization (Martinez et al. 2001). In addition, these reporter mice showed robust Id1-LacZ expression in tip cells of developing ducts, when those were stimulated with BMPs in explanted organ cultures, which is compatible with the reports cited earlier on differences between in vivo studies and explanted organoid culture studies. 
K. Kahata et al.

To address the overall roles of TGF- $\beta$ family members in kidney development, Smad4 was inactivated in mice. Inactivation of Smad4 expression in collecting duct and ureteric buds using Cre recombinase expressed from the Hoxb7 promoter results in apparently normal development, but Cre-mediated Smad4 inactivation in the nephric mesenchyme using the $B m p 7$ promoter results in lack of proper contacts of the mesenchyme with the adjacent ureteric bud, leading to disorganized tissue development (Oxburgh et al. 2004). Another mouse model of Smad4 inactivation in the ureteral and bladder mesenchyme showed no effect in the kidney proper or the urothelium, but resulted in hydronephrosis and obstruction of the ureteropelvic junction (Tripathi et al. 2012). This model showed a clear quantitative defect in smooth muscle differentiation and a reduction in tissue contractility that underlies the obstructive phenotype; however, the overall kidney morphogenesis could be completed despite the absence of Smad4. These Smad4 ${ }^{-/-}$mice showed less severe phenotypes compared with the $B m p 4^{-/-}$mice in the same tissue, illustrating that Smad4 is not essential for all BMP-4 signaling responses.

Although BMPs clearly are major players of the TGF- $\beta$ family in the kidney, activin A inhibits and follistatin enhances branching morphogenesis in culture (Kojima et al. 2001). Similar to the BMP receptors, the ActRII receptor is localized at the tips of ureteric buds and in the associated mesenchyme, and a dominant-negative mutant ActRII receptor expressed by an adenoviral vector blocks the inhibitory effects of activin A on explanted kidney organ cultures (Maeshima et al. 2003). Thus, activin signaling can limit branching morphogenesis and simultaneously promote mesenchymal differentiation to nephric epithelium (Fig. 4F).

In renal fibrosis resulting from chronic kidney injury, TGF- $\beta$ also antagonizes the prodifferentiating effects of BMP-7 (Fig. 4A) (Zeisberg et al. 2003). Injury-mediated inflammation induces TGF- $\beta$ secretion, enforcing EMT, followed by excessive extracellular matrix production in fibrotic scars (Zeisberg et al. 2003). In contrast, BMP-7 acts as a repair and restoration factor that counteracts EMT, preserves epithelial characteristics or even reverts mesenchymal cells to epithelial cells (Zeisberg et al. 2003). Although the chronic kidney injury model is robust, cell culture studies challenge the proposed antagonism of TGF- $\beta$-induced EMT by BMP-7, possibly because of the differentiation state of the cell lines used (Dudas et al. 2009). In one report, immortalized human proximal tubule epithelial HK-2 cells undergo EMT in response to TGF- $\beta$, but BMP-7 fails to revert the mesenchymal cells to epithelial cells (Dudas et al. 2009), whereas BMP-7 does induce reversion in another report $(\mathrm{Xu}$ et al. 2009).

The mechanism through which BMP-7 antagonizes TGF- $\beta$-induced EMT in renal epithelial cells may involve the regulation of $I d 2$ expression, which is repressed by TGF- $\beta$ and induced by BMP-7 (Veerasamy et al. 2013); this regulation is also conserved in breast and lens epithelial cells (Kowanetz et al. 2004). Primary porcine urothelial cells undergo EMT in response to TGF- $\beta$ and activate their Smad signaling (Islam et al. 2014). Activation of the Mmp2 gene, encoding matrix metalloproteinase 2, by TGF- $\beta$ depends on Smad2, and activation of the Ctgfgene, encoding connective tissue growth factor, depends on Smad3, whereas activation of the $M m p 9$ gene requires both Smad2 and Smad3 (Islam et al. 2014). Transcriptomic analyses of human kidney epithelial cells in culture identified almost 1000 TGF- $\beta 1$ responsive genes (Campanaro et al. 2007). This study highlights an important role of MAPK signaling in TGF- $\beta$-induced EMT of kidney epithelial cells, whereas a group of genes that is directly regulated in response to TGF- $\beta 1$ promotes dedifferentiation of epithelial cells (Campanaro et al. 2007). A rat model of diabetic nephropathy shows that high glucose leads to induction of TGF- $\beta 1$ expression by the transcription factor KLF6, which then induces EMT and contributes to fibrosis (Holian et al. 2008). A similar study in human HK-2 cells treated with TGF- $\beta 1$ in the presence of low or high glucose shows that high glucose stimulates the expression of endogenous TGF- $\beta 1$ and induces p38 MAPK signaling, which is similar to 
the low glucose condition when combined with added TGF- $\beta 1$ ( Lv et al. 2011). Under either condition, EMT follows, which is accompanied by 38 MAPK-mediated activation of the AP-1 transcriptional complex and induction of Snail expression (Lv et al. 2011).

In cell culture, TGF- $\beta$ blocks the proliferation and terminal differentiation of undifferentiated bladder urothelial cells (Fleming et al. 2012). In contrast, more differentiated cells respond to TGF- $\beta$ only after wounding, and TGF$\beta$ promotes the repair of the wound (Fleming et al. 2012). Interestingly, urothelial cells in culture enhance Smad3 expression, and decrease Smad7 expression and expression of the E3 ubiquitin ligase Smurf2 that targets T $\beta R I$ and Smad2 during differentiation, consistent with an increase in TGF- $\beta$ signaling capacity (Fleming et al. 2012). TGF- $\beta 1$ can also induce autophagy and apoptosis in human renal proximal tubular cells in culture, by activating the expression of the ATG5, ATG7, and BCN1 genes that encode key autophagy mediators ( $\mathrm{Xu}$ et al. 2012). Induction of autophagy correlates with enhanced production of reactive oxygen species that eventually cause apoptosis of the epithelial cells in response to TGF- $\beta$ (Xu et al. 2012). The response of the renal cells resembles the response of hepatocarcinoma cells to TGF- $\beta$ (Kiyono et al. 2009), as the same set of genes and molecular processes that promote autophagy can be regulated by TGF- $\beta$.

Beyond their effects in cell culture, the TGF$\beta$ s play developmental roles in the kidney. Heterozygous $\mathrm{Tg} f b 2^{+/-}$mice show a significant increase in the number of nephrons (Sims-Lucas et al. 2008). An increase in length and number of branches generated during morphogenesis of the ureteric buds causes this phenotype, suggesting that TGF- $\beta 2$ limits the branching morphogenesis (Fig. 4G) (Sims-Lucas et al. 2008). Furthermore, mice lacking one copy of the Tgfbr3 gene encoding the TGF- $\beta$ coreceptor betaglycan, which also binds inhibin (Namwanje and Brown 2016), show supernumerous nephrons, similar to $\mathrm{Tg} f \mathrm{~b} 2^{+/-}$mice, owing to a similar increase in ureteric bud branching (Fig. 4G) (Walker et al. 2011). On the other hand, complete loss of the Tgfbr3 gene reduces the overall size of the kidney and number of nephrons, showing an opposite phenotype to the heterozygous condition and suggesting dosedependent effects by this coreceptor (Walker et al. 2011). The betaglycan effects correlate best with the expression of BMP-4, which is transiently reduced in $\mathrm{Tgfbr} 3^{+/-}$mice, yet is stably normal in $\mathrm{Tgfbr} 3^{-1-}$ mice at the early stages of kidney development (Walker et al. 2011). Further analysis of the coupling between $\mathrm{Tgfbr} 3$ copy number and expression levels with the process of ureteric bud morphogenesis is needed to explain the full contribution of this coreceptor. Overall, the kidney epithelium provides a rich biological system to understand the developmental and homeostatic roles of the TGF- $\beta$ family, and its dysregulation underlies multiple pathologies, including renal cancer. In particular, mechanisms of BMP-dependent regulation of kidney morphogenesis require better understanding of key developmental transcription factors and signaling mediators that control branching morphogenesis and differentiation.

\section{THE TGF- $\beta$ FAMILY IN LUNG ORGANOGENESIS AND EMT}

Since the early days of TGF- $\beta$ research, pulmonary epithelial cells have been an attractive model for cell culture studies, because TGF- $\beta 1$ causes a strong inhibition of bronchial epithelial cell proliferation and promotes epithelial cell differentiation to a squamous cell phenotype (Masui et al. 1986). In addition, the mink lung epithelial cell model Mv1Lu has been useful in delineating the antiproliferative signaling pathway downstream from TGF- $\beta$, including the identification and functional verification of the TGF- $\beta$ receptors (Tucker et al. 1984; Laiho et al. 1990). Both latent and mature TGF- $\beta 1$ are present in the extracellular matrix of developing lung epithelial cells (Heine et al. 1990), and coincide with the onset of branching morphogenesis in the developing lung. TGF- $\beta 1$ inhibits branching morphogenesis in ex vivo cultures of developing lung buds (Serra et al. 1994). N-Myc is a key transcription factor that drives morphogenesis in the lung and TGF- $\beta 1$ 
K. Kahata et al.

represses N-Myc expression in the lung buds (Serra et al. 1994). Adenoviral expression of an active form of TGF- $\beta 1$ in developing lungs of rats results in inhibition of embryonic lung morphogenesis and repression of N-Myc expression (Fig. 5) (Gauldie et al. 2003). In contrast, TGF- $\beta 1$ delivery into the lungs of adult animals leads to induction of fibrosis and excessive branching in the already developed alveolar network (Gauldie et al. 2003).

Increased TGF- $\beta 1$ expression induces synthesis of collagen and other extracellular matrix proteins, resulting in abnormal alveoli with extended and dilated morphology as a result of decreased cell numbers caused by the antiproliferative and proapoptotic effects of TGF- $\beta 1$ (Gauldie et al. 2003). Tgfb3 ${ }^{-/-}$mice die right after birth because of major defects in completion of lung morphogenesis and palatogenesis (Kaartinen et al. 1995), establishing that also TGF- $\beta 3$ controls lung morphogenesis (Fig. 5). Ex vivo experiments with rat lung buds at early stages of lung morphogenesis, when all three TGF- $\beta$ s and all receptor types are expressed, show that TGF- $\beta 2$, but not TGF- $\beta 1$ or TGF$\beta 3$, acting through T $\beta$ RII and T $\beta$ RI, promotes lung bud morphogenesis, because antisense oligonucleotides against TGF- $\beta 2$ strongly inhibit morphogenesis (Liu et al. 2000). The effect of TGF- $\beta 2$ is concentration-dependent, with low concentrations promoting lung branching morphogenesis and higher concentrations inhibiting the morphogenesis (Liu et al. 2000). Similar studies in mouse and human lungs emphasize a role of TGF- $\beta$ activity during late phases of lung morphogenesis (Alejandre-Alcazar et al. 2008). A more thorough analysis of the role of the distinct TGF- $\beta$ s during the various phases of lung development is still required.

The developed lung is made of several cell types at different anatomical locations. Epithelial cells that provide the lining in small bronchioles are thought to be adult stem cells and are called Clara cells. Genetic ablation of T $\beta$ RI receptor expression in lung progenitor cells blocks Clara cell differentiation (Xing et al. 2010). Furthermore, T $\beta R I$ activates the expression of the HES1 transcription factor, represses the expression of PTEN phosphatase, and activates Erk MAPK and Akt signaling (Xing et al. 2010). Selective Tgfbr1 inactivation in mesodermal progenitor cells results in mesodermal hypoplasia and maturation of the morphogenetic process in the lungs ( $\mathrm{Li}$ et al. 2016). Conditional inactivation of T $\beta$ RII expression in developing lung epithelial cells causes a delay in the differ-

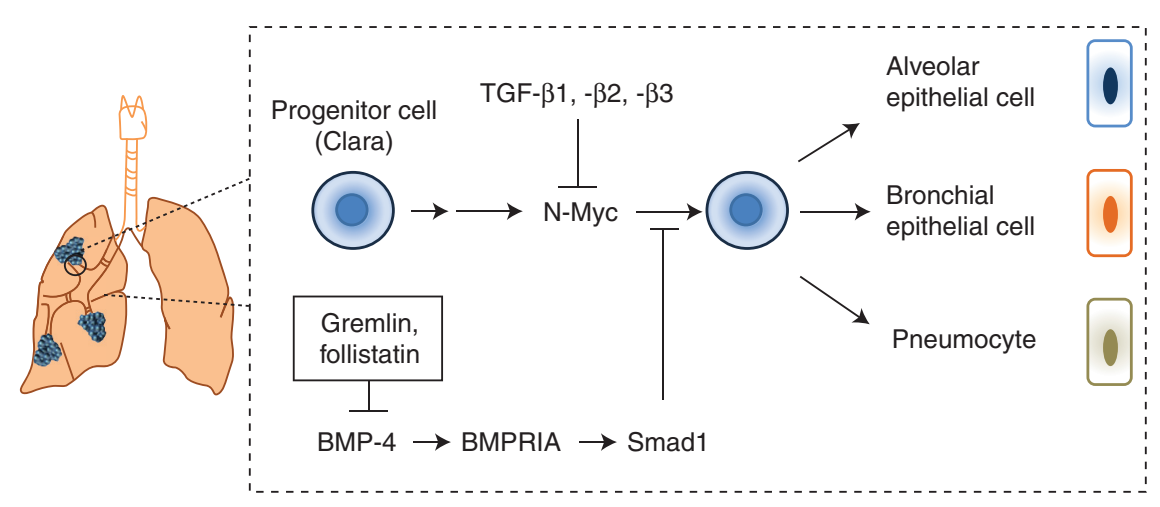

Figure 5. Role of the TGF- $\beta$ family in lung organogenesis. Both TGF- $\beta$ and bone morphogenetic protein (BMP) repress the differentiation of early lung progenitor cells, also known as Clara cells. TGF- $\beta 1,-\beta 2$, and - $\beta 3$ inhibit the morphogenetic program of lung development by repressing the expression of the transcription factor $\mathrm{N}$ Myc, which, together with other transcription factors, promotes the generation of the three major epithelial cells types in the lung alveolar epithelial cells, bronchial epithelial cells, and pneumocytes. Extracellular Gremlin and follistatin inhibit BMP-4 binding to its receptors. Thus, although BMP-4 signaling by BMPRIA and Smad1 repress lung epithelial cell differentiation, the action of the extracellular antagonists provides positive signals to this morphogenetic program. 
entiation of alveoli because of lack of type I alveolar epithelial cells, a phenotype that is expressed only after birth of the mice (Chen et al. 2008). In contrast, ablation of the T $\beta$ RII receptor from the lung mesenchyme affects mildly the branching pattern, leading to defects in neighboring tissues such as the diaphragm (Chen et al. 2008).

Endodermal cells also contribute to the final morphogenesis of the developing lung. Specific ablation of T $\beta$ RII in the mouse lung followed by culture of lung endodermal explants shows that TGF- $\beta$ no longer inhibits branching morphogenesis (Xing et al. 2008). In the lung endoderm, TGF- $\beta$ inhibits cell proliferation and the action of transcription factor $\mathrm{Nkx} 2.1$, also known as thyroid transcription factor, TTF-1, which controls branching of the tissue (Xing et al. 2008). In agreement with the inhibition of lung branching morphogenesis by TGF- $\beta$, antisense oligonucleotides that silence the expression of Smad2 or Smad3 or that of Smad4 enhance lung branching in mouse embryos (Zhao et al. 1998). The effect of Smad4 ablation is surprising in view of Smad4's function in many TGF- $\beta$ family pathways (see below). In addition, TGF- $\beta 1$ failed to rescue the enhanced morphogenesis caused by Smad silencing when added to lung bud explants in vitro (Zhao et al. 1998). Similarly, infection of lung explants in culture with a Smad7-expressing adenovirus blocks the inhibition of cell proliferation and differentiation by TGF- $\beta$, whereas Smad6 does not have a similar impact, which is compatible with the specificity of the inhibitory Smads (Zhao et al. 2000). In addition to Smad signaling, p38 MAPK signaling is induced by TGF- $\beta$ in airway epithelial cells in culture and promotes apoptosis (Undevia et al. 2004). However, more research is needed to better define all effects of TGF- $\beta$ in the various cell types of the developing lung and to link TGF- $\beta$ signaling activities to genomic and chromatin-mediated transcriptomic changes during lung epithelial differentiation, as revealed by genome-wide studies (Marconett et al. 2013).

The BMP family has been ascribed a similar function as TGF- $\beta$ in lung epithelial differentiation. Transgenic mice that conditionally over- express BMP-4 in the distal epithelium of the developing lung tissue, the normal site of BMP4 expression, suffer from small size lungs that lack properly developed airways and are full of large air sacs (Bellusci et al. 1996). Excess of BMP-4 inhibits proliferation of progenitor cells and inhibits terminal differentiation of type II pneumocytes (Bellusci et al. 1996). The role of BMP-4 in patterning the proximal-distal polarity of the developing lungs has also been confirmed using transgenic mice expressing noggin or a dominant-negative BMPRIB receptor, both resulting in loss of BMP signaling, leading to loss of distal epithelial cells and enrichment in proximal epithelial cells in the resulting abnormal lungs (Weaver et al. 1999). Peripheral (distal) BMP-4 is inactivated by extracellular Gremlin (Fig. 5), which is highly expressed in buds when branching morphogenesis starts and in more developed airways (Shi et al. 2001). Silencing of Gremlin expression using antisense oligonucleotides in lung bud explant cultures has the same effect as adding BMP-4, both leading to enhanced branching morphogenesis (Shi et al. 2001). Conversely, transgenic overexpression of Gremlin in the distal lung epithelium in mice disrupts the proximal-distal pattern of development and promotes proximal epithelial expansion at the expense of distal epithelial differentiation ( $\mathrm{Lu}$ et al. 2001). Follistatin, best known for its antagonistic effects against activins, also binds BMP-4 and blocks its signaling function (Fig. 5). Accordingly, inactivation of follistatin expression in mice results in death from respiratory failure, because of abnormal development of the trachea and failure in differentiation of the distal alveolar epithelial cells (Geng et al. 2011). Lack of follistatin expression causes enhanced BMP signaling, which was shown by administration of noggin that rescues the lung defects (Geng et al. 2011).

Heparan sulfate glycosaminoglycan chains in extracellular proteoglycans represent another important determinant of BMP activity in the developing lung. Indeed, targeted inactivation of the Ndst1 gene, which encodes N-deacetylase/N-sulfotransferase-1, an enzyme involved in heparan sulfate synthesis, causes defective lung epithelial differentiation because of en- 
K. Kahata et al.

hanced BMP signaling (Hu et al. 2009). Addition of heparin in cell culture can rescue overactive BMP signaling and normalizes BMP actions on lung epithelial differentiation ( $\mathrm{Hu}$ et al. 2009).

The BMPRIA receptor is expressed in the developing lung epithelium, and conditional inactivation of its expression in mouse lung epithelium resulting from Cre recombinase expression from the $S f t p c$ promoter causes low epithelial cell proliferation and high cell death, resulting in loss of differentiated type II pneumocytes (Eblaghie et al. 2006). Inactivation of the Bmprla gene during early lung morphogenesis or after birth results in detrimental lung function and eventual collapse (Fig. 5) (Sun et al. 2008). Early gene ablation delays branching morphogenesis and differentiation, whereas late ablation affects the proliferation and physiological secretion of lung epithelial cells, both leading to severe lung defects (Sun et al. 2008).

BMP-4 signaling through BMPRIA during lung development involves Smad1 (Fig. 5), because silencing Smad1 expression using antisense oligonucleotides in ex vivo cultures of lung buds reduces the branching and epithelial cell differentiation (Chen et al. 2005). Comparing the effects of lung epithelial cell-specific inactivation of Smad1 versus Smad5 expression in lung development using Cre expression from the Sftpc promoter suggests a major role for Smad1, as its ablation results in reduced branching morphogenesis and distal epithelial cell differentiation (Xu et al. 2011). Accordingly, adenoviral delivery of the E3 ubiquitin ligase Smurf1, which targets BMPRIA and Smad1, in the lung blocks branching and epithelial differentiation while reducing the total Smad1 and Smad5 levels, but not the Smad8 levels (Shi et al. 2004). The BMP-4-BMPRIA-Smad1 pathway induces expression of the Wnt inhibitory factor-1 (WIF-1), which limits the action of Wnt signaling during lung differentiation $(\mathrm{Xu}$ et al. 2011).

Reporter mice have been instrumental to trace BMP signaling in the lung throughout development, adult life and during pathogenesis (Sountoulidis et al. 2012). Using the Id1 promoter driving GFP expression, BMP-Smad sig- naling activity can be traced in progenitor cells of the proximal developing airway and in alveolar epithelial cells, whereas BMP signaling activity dissipates in adult lungs, unless tissue damage and remodeling are activated by injury (Sountoulidis et al. 2012). These findings agree with immunocytochemistry results for activated Smad1 and Smad5 and expression of their target genes encoding $\operatorname{Id} 1, \operatorname{Id} 2$, and $\operatorname{Id} 3$, and show that the BMP pathway is especially active during late stages of lung morphogenesis (Alejandre-Alcazar et al. 2007). Additional studies on the dynamics of BMP signaling after injury of the mouse trachea indicate activity in basal stem cells, which contribute to the regeneration of ciliated and secretory lung epithelium (Tadokoro et al. 2016). These experiments once again confirm that BMP signaling limits lung epithelial cell proliferation during periods of generation of new epithelia from basal cells, and emphasize the role of secreted extracellular BMP inhibitors, which limit the signaling power of the BMPs (Tadokoro et al. 2016).

The anti-Müllerian hormone (AMH), also known as Müllerian inhibiting substance (MIS), plays a critical role in the development of the male reproductive tract, but has also been implicated in lung morphogenesis. In vivo, developing lung epithelium expresses both the AMH ligand and its type II receptor AMHRII (Catlin et al. 1997). Ex vivo, AMH causes retardation of lung bud growth with strong signs of localized apoptosis within the bud mass (Catlin et al. 1997).

The pivotal role of BMP signaling in lung morphogenesis is also illustrated by studies of ESC differentiation. ESCs can generate differentiated lung epithelial cells through intermediate stages that are controlled by activin, nodal, and noggin (Ninomiya et al. 2013). ESCs in culture can differentiate into definitive endoderm, followed by generation of pulmonary endoderm that contains lung progenitor cells marked by the expression of Nkx2.1, a stage dependent on activin A signaling (Li et al. 2013). Activin A signals through ActRIB and Smad2, which then induces transcription of the Nkx2-1 gene (Li et al. 2013). Subsequently, limited BMP-4 signaling, achieved by noggin in the differenti- 
ation cocktail, promotes differentiation of distal epithelial cells, such as Clara and goblet cells (Ninomiya et al. 2013). A similar protocol starting from human pluripotent stem cells generates all differentiated cell types of the mature lung and thus promises its application to therapy of lung injury (Huang et al. 2014).

Similar to other epithelial cell types, lung epithelial cells can undergo EMT. For example, in response to TGF- $\beta$ signaling through Smad2, Smad3, and Smad4, A549 adenocarcinoma cells, which are of alveolar type II epithelial origin, can transition into fusiform mesenchymal cells with extensive cytoskeletal remodeling, and type II cells can transdifferentiate into type I cells (Kasai et al. 2005; Bhaskaran et al. 2007; Buckley et al. 2012). The nuclear Smads form complexes with $\beta$-catenin and activate the gene encoding $\alpha$-SMA that characterizes the myofibroblast differentiation on TGF- $\beta$ stimulation (Zhou et al. 2012). Similarly, BMP-4 promotes EMT and excess extracellular matrix secretion in epithelial BAES-2B cells (Molloy et al. 2008). More relevant than EMT is the developmental induction by epithelial-mesenchymal interactions in the lung bud, as described throughout this review. Accordingly, TGF- $\beta$ signaling in the lung mesoderm controls the differentiation into $\alpha$-SMA expressing myofibroblasts versus lipofibroblasts. When TGF- $\beta$ receptor levels are reduced after Tgfrbl inactivation, the lipofibroblasts take over and the decreased numbers of myofibroblasts result in a defective induction of epithelial differentiation and morphogenesis, consistent with the phenotype of these mutant mice (Li et al. 2016).

Thus, TGF- $\beta$ and BMP pathways pattern the normal morphogenesis of the alveolar trees during lung development, contribute to terminal epithelial differentiation, and cause mesenchymal transitions at least in cultured lung epithelial cells, consistent with the potent cell-cycle arrest of these cells. Although epithelial-mesenchymal interactions, especially at the distal alveolar tips of differentiation, depend on continuous inputs from the neighboring mesenchyme or endothelium, a developmental role of EMT has not yet been uncovered in the lung, suggesting that the lung engages the
EMT program only during chronic inflammatory conditions that lead to fibrosis or during cancer progression.

\section{CONCLUSIONS AND PERSPECTIVES}

This review discusses mechanisms by which TGF- $\beta$ family ligands regulate the morphogenesis of ductal tissues leading to the generation of many vital organs in the vertebrate body. The rich knowledge that has been generated on this topic over the years did not allow a full account of all experimental efforts made by the community. An important take-home message is that transgenic mice with tissue-specific inactivation or overexpression of TGF- $\beta$ family ligands, receptors or Smads, provide the central framework for our understanding of how ductal morphogenesis proceeds in an epithelial tissuespecific manner. In addition, tissue-specific adaptations can also be generated based on the activity of the TGF- $\beta$ ligands, which are controlled by their extracellular antagonists. On the other hand, important knowledge of signal transduction mechanisms from culture studies with primary or established cell models remains to be translated into the biological context in vivo. This encompasses the extensive cooperation of the TGF- $\beta$ s with additional signaling networks, including the Wnt and FGF pathways, so that tissue specificity can be generated in these epithelial organs. Future analyses of human ductal development and the contributions of the TGF- $\beta$ s during adult homeostasis or in various pathologies are a fertile area of research. In development of ductal tissue, new research may focus on the time-dependent and sequential signaling events that promote the building of ductal epithelial tissues with the instructive signaling input provided by the adjacent mesenchyme. Because not every TGF- $\beta$ family member has yet been examined for its role in ductal morphogenesis, more work remains until this task will be completely fulfilled.

\section{ACKNOWLEDGMENTS}

We thank all past and present members of the TGF- $\beta$ signaling and STEP groups for their 
K. Kahata et al.

contributions to the scientific work emanating from our laboratory. We thank Carl-Henrik Heldin for his support and guidance and for a thorough reading of the manuscript during preparation. This review summarizes work from a large number of published papers; however, we have been unable to include all relevant publications in our discussion because of space limitations. We apologize to those authors whose relevant work has not been included in this review. We acknowledge funding by the Ludwig Cancer Research, the Swedish Cancer Society, the Swedish Research Council, the Network of Excellence "ENFIN" by the European Union FP6 program, and the Marie Curie Initial Training Network "IT-Liver" by the European Union FP7 program.

\section{REFERENCES}

${ }^{*}$ Reference is also in this subject collection.

Ahnfelt-Ronne J, Ravassard P, Pardanaud-Glavieux C, Scharfmann R, Serup P. 2010. Mesenchymal bone morphogenetic protein signaling is required for normal pancreas development. Diabetes 59: 1948-1956.

Akkari L, Haouzi D, Biname F, Floc'h N, Lassus P, Baghdiguian S, Hibner U. 2010. Cell shape and TGF- $\beta$ signaling define the choice of lineage during in vitro differentiation of mouse primary hepatic precursors. J Cell Physiol 225: 186- 195 .

Alejandre-Alcazar MA, Shalamanov PD, Amarie OV, Sevilla-Perez J, Seeger W, Eickelberg O, Morty RE. 2007. Temporal and spatial regulation of bone morphogenetic protein signaling in late lung development. Dev Dyn 236: 2825-2835.

Alejandre-Alcazar MA, Michiels-Corsten M, Vicencio AG, Reiss I, Ryu J, de Krijger RR, Haddad GG, Tibboel D, Seeger W, Eickelberg O, et al. 2008. TGF- $\beta$ signaling is dynamically regulated during the alveolarization of rodent and human lungs. Dev Dyn 237: 259-269.

Andrzejewski D, Brown ML, Ungerleider N, Burnside A, Schneyer AL. 2015. Activins A and B regulate fate-determining gene expression in islet cell lines and islet cells from male mice. Endocrinology 156: 2440-2450.

Auclair BA, Benoit YD, Rivard N, Mishina Y, Perreault N. 2007. Bone morphogenetic protein signaling is essential for terminal differentiation of the intestinal secretory cell lineage. Gastroenterology 133: 887-896.

Babitt JL, Huang FW, Wrighting DM, Xia Y, Sidis Y, Samad TA, Campagna JA, Chung RT, Schneyer AL, Woolf CJ, et al. 2006. Bone morphogenetic protein signaling by hemojuvelin regulates hepcidin expression. Nat Genet 38: $531-539$.

Ball EM, Risbridger GP. 2001. Activins as regulators of branching morphogenesis. Dev Biol 238: 1-12.
Bardeesy N, Cheng KH, Berger JH, Chu GC, Pahler J, Olson P, Hezel AF, Horner J, Lauwers GY, Hanahan D, et al. 2006. Smad4 is dispensable for normal pancreas development yet critical in progression and tumor biology of pancreas cancer. Genes Dev 20: 3130-3146.

Barnard JA, Beauchamp RD, Coffey RJ, Moses HL. 1989. Regulation of intestinal epithelial cell growth by transforming growth factor type $\beta$. Proc Natl Acad Sci 86: $1578-1582$.

Bellusci S, Henderson R, Winnier G, Oikawa T, Hogan BL. 1996. Evidence from normal expression and targeted misexpression that bone morphogenetic protein (Bmp4) plays a role in mouse embryonic lung morphogenesis. Development 122: 1693-1702.

Bhaskaran M, Kolliputi N, Wang Y, Gou D, Chintagari NR, Liu L. 2007. Trans-differentiation of alveolar epithelial type II cells to type I cells involves autocrine signaling by transforming growth factor $\beta 1$ through the Smad pathway. J Biol Chem 282: 3968-3976.

Bidart M, Ricard N, Levet S, Samson M, Mallet C, David L, Subileau M, Tillet E, Feige JJ, Bailly S. 2012. BMP9 is produced by hepatocytes and circulates mainly in an active mature form complexed to its prodomain. Cell Mol Life Sci 69: 313-324.

Bilezikjian LM, Justice NJ, Blackler AN, Wiater E, Vale WW. 2012. Cell-type specific modulation of pituitary cells by activin, inhibin and follistatin. Mol Cell Endocrinol 359: 43-52.

Biname F, Lassus P, Hibner U. 2008. Transforming growth factor $\beta$ controls the directional migration of hepatocyte cohorts by modulating their adhesion to fibronectin. $\mathrm{Mol}$ Biol Cell 19: 945-956.

Blank U, Seto ML, Adams DC, Wojchowski DM, Karolak MJ, Oxburgh L. 2008. An in vivo reporter of BMP signaling in organogenesis reveals targets in the developing kidney. BMC Dev Biol 8: 86.

Böttinger EP, Jakubczak JL, Roberts IS, Mumy M, Hemmati P, Bagnall K, Merlino G, Wakefield LM. 1997. Expression of a dominant-negative mutant TGF- $\beta$ type II receptor in transgenic mice reveals essential roles for TGF- $\beta$ in regulation of growth and differentiation in the exocrine pancreas. EMBO J 16: 2621-2633.

Buckley ST, Medina C, Davies AM, Ehrhardt C. 2012. Cytoskeletal re-arrangement in TGF- $\beta 1$-induced alveolar epithelial-mesenchymal transition studied by atomic force microscopy and high-content analysis. Nanomedicine 8: 355-364.

Caja L, Bertran E, Campbell J, Fausto N, Fabregat I. 2011. The transforming growth factor- $\beta$ (TGF- $\beta$ ) mediates acquisition of a mesenchymal stem cell-like phenotype in human liver cells. J Cell Physiol 226: 1214-1223.

Campanaro S, Picelli S, Torregrossa R, Colluto L, Ceol M, Del Prete D, D’Angelo A, Valle G, Anglani F. 2007. Genes involved in TGF $\beta 1$-driven epithelial-mesenchymal transition of renal epithelial cells are topologically related in the human interactome map. BMC Genomics 8: 383.

Canali S, Core AB, Zumbrennen-Bullough KB, Merkulova M, Wang CY, Schneyer AL, Pietrangelo A, Babitt JL. 2016. Activin B induces noncanonical SMAD1/5/8 signaling via BMP type I receptors in hepatocytes: Evidence for a role in hepcidin induction by inflammation in male mice. Endocrinology 157: 1146-1162. 
Cancilla B, Jarred RA, Wang H, Mellor SL, Cunha GR, Risbridger GP. 2001. Regulation of prostate branching morphogenesis by activin A and follistatin. Dev Biol 237: $145-158$.

Cao Y, Liu X, Zhang W, Deng X, Zhang H, Liu Y, Chen L, Thompson EA, Townsend CMJr, Ko TC. 2009. TGF- $\beta$ repression of Id 2 induces apoptosis in gut epithelial cells. Oncogene 28: 1089-1098.

Catlin EA, Tonnu VC, Ebb RG, Pacheco BA, Manganaro TF, Ezzell RM, Donahoe PK, Teixeira J. 1997. Müllerian inhibiting substance inhibits branching morphogenesis and induces apoptosis in fetal rat lung. Endocrinology 138: 790-796.

Chang WY, Birch L, Woodham C, Gold LI, Prins GS. 1999. Neonatal estrogen exposure alters the transforming growth factor- $\beta$ signaling system in the developing rat prostate and blocks the transient $\mathrm{p} 21^{\text {cip } 1 / \text { waf1 }}$ expression associated with epithelial differentiation. Endocrinology 140: $2801-2813$.

Chen C, Chen H, Sun J, Bringas PJr, Chen Y, Warburton D, Shi W. 2005. Smadl expression and function during mouse embryonic lung branching morphogenesis. Am J Physiol Lung Cell Mol Physiol 288: L1033-1039.

Chen H, Zhuang F, Liu YH, Xu B, Del Moral P, Deng W, Chai Y, Kolb M, Gauldie J, Warburton D, et al. 2008. TGF- $\beta$ receptor II in epithelia versus mesenchyme plays distinct roles in the developing lung. Eur Respir J 32: 285-295.

Chi L, Saarela U, Railo A, Prunskaite-Hyyrylainen R, Skovorodkin I, Anthony S, Katsu K, Liu Y, Shan J, Salgueiro AM, et al. 2011. A secreted BMP antagonist, Cer1, fine tunes the spatial organization of the ureteric bud tree during mouse kidney development. PLoS ONE 6: e27676.

Chou WC, Prokova V, Shiraishi K, Valcourt U, Moustakas A, Hadzopoulou-Cladaras M, Zannis VI, Kardassis D. 2003. Mechanism of a transcriptional cross talk between transforming growth factor- $\beta$-regulated Smad 3 and Smad 4 proteins and orphan nuclear receptor hepatocyte nuclear factor-4. Mol Biol Cell 14: 1279-1294.

Cicchini C, Laudadio I, Citarella F, Corazzari M, Steindler C, Conigliaro A, Fantoni A, Amicone L, Tripodi M. 2008. TGF $\beta$-induced EMT requires focal adhesion kinase (FAK) signaling. Exp Cell Res 314: 143-152.

Claisse D, Martiny I, Chaqour B, Wegrowski Y, Petitfrere E, Schneider C, Haye B, Bellon G. 1999. Influence of transforming growth factor $\beta 1$ (TGF- $\beta 1$ ) on the behaviour of porcine thyroid epithelial cells in primary culture through thrombospondin-1 synthesis. J Cell Sci 112: 1405-1416.

Cocolakis E, Dai M, Drevet L, Ho J, Haines E, Ali S, Lebrun JJ. 2008. Smad signaling antagonizes STAT5-mediated gene transcription and mammary epithelial cell differentiation. J Biol Chem 283: 1293-1307.

Colletta G, Cirafici AM, Di Carlo A. 1989. Dual effect of transforming growth factor $\beta$ on rat thyroid cells: Inhibition of thyrotropin-induced proliferation and reduction of thyroid-specific differentiation markers. Cancer Res 49: 3457-3462.

Cook C, Vezina CM, Allgeier SH, Shaw A, Yu M, Peterson RE, Bushman W. 2007. Noggin is required for normal lobe patterning and ductal budding in the mouse prostate. Dev Biol 312: 217-230. de Andrade Sa ER, Bitencourt B, Alvares EP, Gama P. 2008. In vivo effects of TGF $\beta 1$ on the growth of gastric epithelium in suckling rats. Regul Pept 146: 293-302.

De Robertis EM. 2009. Spemann's organizer and the selfregulation of embryonic fields. Mech Dev 126: 925-941.

del Castillo G, Alvarez-Barrientos A, Carmona-Cuenca I, Fernandez M, Sanchez A, Fabregat I. 2008. Isolation and characterization of a putative liver progenitor population after treatment of fetal rat hepatocytes with TGF- $\beta$. J Cell Physiol 215: 846-855.

Dhawan S, Dirice E, Kulkarni RN, Bhushan A. 2016. Inhibition of TGF- $\beta$ signaling promotes human pancreatic $\beta$-cell replication. Diabetes 65: 1208-1218.

Dudas PL, Argentieri RL, Farrell FX. 2009. BMP-7 fails to attenuate TGF- $\beta 1$-induced epithelial-to-mesenchymal transition in human proximal tubule epithelial cells. Nephrol Dial Transplant 24: 1406-1416.

Dudley AT, Godin RE, Robertson EJ. 1999. Interaction between FGF and BMP signaling pathways regulates development of metanephric mesenchyme. Genes Dev 13: 1601-1613.

Eblaghie MC, Reedy M, Oliver T, Mishina Y, Hogan BL. 2006. Evidence that autocrine signaling through Bmprla regulates the proliferation, survival and morphogenetic behavior of distal lung epithelial cells. Dev Biol 291: 6782.

Faure S, McKey J, Sagnol S, de Santa Barbara P. 2015. Enteric neural crest cells regulate vertebrate stomach patterning and differentiation. Development 142: 331-342.

Fetting JL, Guay JA, Karolak MJ, Iozzo RV, Adams DC, Maridas DE, Brown AC, Oxburgh L. 2014. FOXD1 promotes nephron progenitor differentiation by repressing decorin in the embryonic kidney. Development 141: 17-27.

Fleming JM, Shabir S, Varley CL, Kirkwood LA, White A, Holder J, Trejdosiewicz LK, Southgate J. 2012. Differentiation-associated reprogramming of the transforming growth factor $\beta$ receptor pathway establishes the circuitry for epithelial autocrine/paracrine repair. PLOS ONE 7: e51404.

Fornetti J, Flanders KC, Henson PM, Tan AC, Borges VF, Schedin P. 2016. Mammary epithelial cell phagocytosis downstream of TGF- $\beta 3$ is characterized by adherens junction reorganization. Cell Death Differ 23: 185-196.

Forrester E, Chytil A, Bierie B, Aakre M, Gorska AE, SharifAfshar AR, Muller WJ, Moses HL. 2005. Effect of conditional knockout of the type II TGF- $\beta$ receptor gene in mammary epithelia on mammary gland development and polyomavirus middle T antigen induced tumor formation and metastasis. Cancer Res 65: 2296-2302.

Forsman CL, Ng BC, Heinze RK, Kuo C, Sergi C, Gopalakrishnan R, Yee D, Graf D, Schwertfeger KL, Petryk A. 2013. BMP-binding protein twisted gastrulation is required in mammary gland epithelium for normal ductal elongation and myoepithelial compartmentalization. Dev Biol 373: 95-106.

Franco DL, Mainez J, Vega S, Sancho P, Murillo MM, de Frutos CA, Del Castillo G, Lopez-Blau C, Fabregat I, Nieto MA. 2010. Snaill suppresses TGF- $\beta$-induced apoptosis and is sufficient to trigger EMT in hepatocytes. $J$ Cell Sci 123: 3467-3477.

Fukamachi H, Kato S, Asashima M, Ichinose M, Yuasa Y. 2013. Activin A regulates growth of gastro-intestinal ep- 
K. Kahata et al.

ithelial cells by mediating epithelial-mesenchymal interaction. Dev Growth Differ 55: 786-791.

Gal A, Sjöblom T, Fedorova L, Imreh S, Beug H, Moustakas A. 2008. Sustained TGF $\beta$ exposure suppresses Smad and non-Smad signalling in mammary epithelial cells, leading to EMTand inhibition of growth arrest and apoptosis. Oncogene 27: 1218-1230.

Gauldie J, Galt T, Bonniaud P, Robbins C, Kelly M, Warburton D. 2003. Transfer of the active form of transforming growth factor- $\beta 1$ gene to newborn rat lung induces changes consistent with bronchopulmonary dysplasia. Am J Pathol 163: 2575-2584.

Geng Y, Dong Y, Yu M, Zhang L, Yan X, Sun J, Qiao L, Geng H, Nakajima M, Furuichi T, et al. 2011. Follistatin-like 1 (Fstl1) is a bone morphogenetic protein (BMP) 4 signaling antagonist in controlling mouse lung development. Proc Natl Acad Sci 108: 7058-7063.

Godin RE, Takaesu NT, Robertson EJ, Dudley AT. 1998. Regulation of BMP7 expression during kidney development. Development 125: 3473-3482.

Godin RE, Robertson EJ, Dudley AT. 1999. Role of BMP family members during kidney development. Int J Dev Biol 43: 405-411.

Gold E, Jetly N, O’Bryan MK, Meachem S, Srinivasan D, Behuria S, Sanchez-Partida LG, Woodruff T, Hedwards S, Wang $\mathrm{H}$, et al. 2009. Activin C antagonizes activin A in vitro and overexpression leads to pathologies in vivo. $\mathrm{Am}$ J Pathol 174: 184-195.

Goncalves A, Zeller R. 2011. Genetic analysis reveals an unexpected role of BMP7 in initiation of ureteric bud outgrowth in mouse embryos. PLoS ONE 6: e19370.

Gorska AE, Joseph H, Derynck R, Moses HL, Serra R. 1998. Dominant-negative interference of the transforming growth factor $\beta$ type II receptor in mammary gland epithelium results in alveolar hyperplasia and differentiation in virgin mice. Cell Growth Differ 9: 229-238.

Grände M, Franzen A, Karlsson JO, Ericson LE, Heldin NE, Nilsson M. 2002. Transforming growth factor- $\beta$ and epidermal growth factor synergistically stimulate epithelial to mesenchymal transition (EMT) through a MEK-dependent mechanism in primary cultured pig thyrocytes. $J$ Cell Sci 115: 4227-4236.

Grisaru S, Cano-Gauci D, Tee J, Filmus J, Rosenblum ND. 2001. Glypican-3 modulates BMP- and FGF-mediated effects during renal branching morphogenesis. Dev Biol 231: $31-46$.

Grishina IB, Kim SY, Ferrara C, Makarenkova HP, Walden PD. 2005. BMP7 inhibits branching morphogenesis in the prostate gland and interferes with Notch signaling. Dev Biol 288: 334-347.

Hall BE, Zheng C, Swaim WD, Cho A, Nagineni CN, Eckhaus MA, Flanders KC, Ambudkar IS, Baum BJ, Kulkarni AB. 2010. Conditional overexpression of TGF- $\beta 1$ disrupts mouse salivary gland development and function. Lab Invest 90: 543-555.

Hanley S, Rosenberg L. 2007. Transforming growth factor $\beta$ is a critical regulator of adult human islet plasticity. $\mathrm{Mol}$ Endocrinol 21: 1467-1477.

Haramis AP, Begthel H, van den Born M, van Es J, Jonkheer S, Offerhaus GJ, Clevers H. 2004. De novo crypt formation and juvenile polyposis on BMP inhibition in mouse intestine. Science 303: 1684-1686.
Hardy G, Kramer B. 2000. Spatial and temporal localisation of bone morphogenetic protein-3 (osteogenin) in the developing rat submandibular gland. SADJ 55: 136-141.

Hartwig S, Bridgewater D, Di Giovanni V, Cain J, Mishina Y, Rosenblum ND. 2008. BMP receptor ALK3 controls collecting system development. J Am Soc Nephrol 19: 117124.

Hay ED. 1995. An overview of epithelio-mesenchymal transformation. Acta Anat 154: 8-20.

He XC, Zhang J, Tong WG, Tawfik O, Ross J, Scoville DH, Tian Q, Zeng X, He X, Wiedemann LM, et al. 2004. BMP signaling inhibits intestinal stem cell self-renewal through suppression of Wnt- $\beta$-catenin signaling. Nat Genet 36: 1117-1121.

Heikinheimo KA, Laine MA, Ritvos OV, Voutilainen RJ, Hogan BL, Leivo IV. 1999. Bone morphogenetic protein-6 is a marker of serous acinar cell differentiation in normal and neoplastic human salivary gland. Cancer Res 59: 5815-5821.

Heine UI, Munoz EF, Flanders KC, Roberts AB, Sporn MB. 1990. Colocalization of TGF- $\beta 1$ and collagen I and III, fibronectin and glycosaminoglycans during lung branching morphogenesis. Development 109: 29-36.

Hens JR, Dann P, Zhang JP, Harris S, Robinson GW, Wysolmerski J. 2007. BMP4 and PTHrP interact to stimulate ductal outgrowth during embryonic mammary development and to inhibit hair follicle induction. Development 134: 1221-1230.

Hesling C, Lopez J, Fattet L, Gonzalo P, Treilleux I, Blanchard D, Losson R, Goffin V, Pigat N, Puisieux A, et al. 2013. Tifl $\gamma$ is essential for the terminal differentiation of mammary alveolar epithelial cells and for lactation through SMAD4 inhibition. Development 140: 167-175.

Hogan BL. 1996. Bone morphogenetic proteins: Multifunctional regulators of vertebrate development. Genes Dev 10: $1580-1594$.

Holian J, Qi W, Kelly DJ, Zhang Y, Mreich E, Pollock CA, Chen XM. 2008. Role of Krüppel-like factor 6 in transforming growth factor- $\beta 1$-induced epithelial-mesenchymal transition of proximal tubule cells. Am J Physiol Renal Physiol 295: F1388-1396.

Hu MC, Piscione TD, Rosenblum ND. 2003. Elevated SMAD1/ $\beta$-catenin molecular complexes and renal medullary cystic dysplasia in ALK3 transgenic mice. Development 130: 2753-2766.

Hu MC, Wasserman D, Hartwig S, Rosenblum ND. 2004. p38MAPK acts in the BMP7-dependent stimulatory pathway during epithelial cell morphogenesis and is regulated by Smad1. J Biol Chem 279: 12051-12059.

Hu Z, Wang C, Xiao Y, Sheng N, Chen Y, Xu Y, Zhang L, Mo W, Jing N, Hu G. 2009. NDST1-dependent heparan sulfate regulates BMP signaling and internalization in lung development. J Cell Sci 122: 1145-1154.

Hua H, Zhang YQ, Dabernat S, Kritzik M, Dietz D, Sterling L, Sarvetnick N. 2006. BMP4 regulates pancreatic progenitor cell expansion through Id2. J Biol Chem 281: 13574-13580.

Huang SX, Islam MN, O’Neill J, Hu Z, Yang YG, Chen YW, Mumau M, Green MD, Vunjak-Novakovic G, Bhattacharya J, et al. 2014. Efficient generation of lung and airway epithelial cells from human pluripotent stem cells. Nat Biotechnol 32: 84-91. 
Ingman WV, Robertson SA. 2008. Mammary gland development in transforming growth factor $\beta 1$ null mutant mice: Systemic and epithelial effects. Biol Reprod 79: $711-717$.

Islam SS, Mokhtari RB, El Hout Y, Azadi MA, Alauddin M, Yeger H, Farhat WA. 2014. TGF- $\beta 1$ induces EMT reprogramming of porcine bladder urothelial cells into collagen producing fibroblasts-like cells in a Smad2/Smad3 dependent manner. J Cell Commun Signal 8: 39-58.

Itäranta P, Chi L, Seppänen T, Niku M, Tuukkanen J, Peltoketo $\mathrm{H}$, Vainio S. 2006. Wnt-4 signaling is involved in the control of smooth muscle cell fate via Bmp-4 in the medullary stroma of the developing kidney. Dev Biol 293: 473-483.

Jahchan NS, Wang D, Bissell MJ, Luo K. 2012. SnoN regulates mammary gland alveologenesis and onset of lactation by promoting prolactin/Stat5 signaling. Development 139: 3147-3156.

Janebodin K, Buranaphatthana W, Ieronimakis N, Hays AL, Reyes M. 2013. An in vitro culture system for long-term expansion of epithelial and mesenchymal salivary gland cells: Role of TGF- $\beta 1$ in salivary gland epithelial and mesenchymal differentiation. Biomed Res Int 2013: 815895.

Jhappan C, Geiser AG, Kordon EC, Bagheri D, Hennighausen L, Roberts AB, Smith GH, Merlino G. 1993. Targeting expression of a transforming growth factor $\beta 1$ transgene to the pregnant mammary gland inhibits alveolar development and lactation. EMBO J 12: 1835-1845.

Jiang M, Ku WY, Zhou Z, Dellon ES, Falk GW, Nakagawa H, Wang ML, Liu K, Wang J, Katzka DA, et al. 2015. BMPdriven NRF2 activation in esophageal basal cell differentiation and eosinophilic esophagitis. J Clin Invest 125: 1557-1568.

Joseph H, Gorska AE, Sohn P, Moses HL, Serra R. 1999. Overexpression of a kinase-deficient transforming growth factor- $\beta$ type II receptor in mouse mammary stroma results in increased epithelial branching. Mol Biol Cell 10: 1221-1234.

Ju W, Ogawa A, Heyer J, Nierhof D, Yu L, Kucherlapati R, Shafritz DA, Böttinger EP. 2006. Deletion of Smad2 in mouse liver reveals novel functions in hepatocyte growth and differentiation. Mol Cell Biol 26: 654-667.

Kaartinen V, Voncken JW, Shuler C, Warburton D, Bu D, Heisterkamp N, Groffen J. 1995. Abnormal lung development and cleft palate in mice lacking TGF- $\beta 3$ indicates defects of epithelial-mesenchymal interaction. $\mathrm{Nat} \mathrm{Ge}$ net 11: 415-421.

Kaimori A, Potter J, Kaimori JY, Wang C, Mezey E, Koteish A. 2007. Transforming growth factor- $\beta 1$ induces an epithelial-to-mesenchymal transition state in mouse hepatocytes in vitro. J Biol Chem 282: 22089-22101.

Karsenty G, Luo G, Hofmann C, Bradley A. 1996. BMP 7 is required for nephrogenesis, eye development, and skeletal patterning. Ann NY Acad Sci 785: 98-107.

Kasai H, Allen JT, Mason RM, Kamimura T, Zhang Z. 2005. TGF- $\beta 1$ induces human alveolar epithelial to mesenchymal cell transition (EMT). Respir Res 6: 56.

Keil KP, Altmann HM, Abler LL, Hernandez LL, Vezina CM. 2015. Histone acetylation regulates prostate ductal morphogenesis through a bone morphogenetic protein-dependent mechanism. Dev Dyn 244: 1404-1414.
Kim SK, Hebrok M. 2001. Intercellular signals regulating pancreas development and function. Genes Dev 15: $111-127$.

Kiyono K, Suzuki HI, Matsuyama H, Morishita Y, Komuro A, Kano MR, Sugimoto K, Miyazono K. 2009. Autophagy is activated by TGF- $\beta$ and potentiates TGF- $\beta$-mediated growth inhibition in human hepatocellular carcinoma cells. Cancer Res 69: 8844-8852.

Klein D, Alvarez-Cubela S, Lanzoni G, Vargas N, Prabakar KR, Boulina M, Ricordi C, Inverardi L, Pastori RL, Dominguez-Bendala J. 2015. BMP-7 induces adult human pancreatic exocrine-to-endocrine conversion. Diabetes 64: $4123-4134$.

Kohn EA, Du Z, Sato M, Van Schyndle CM, Welsh MA, Yang YA, Stuelten CH, Tang B, Ju W, Böttinger EP, et al. 2010. A novel approach for the generation of genetically modified mammary epithelial cell cultures yields new insights into TGF $\beta$ signaling in the mammary gland. Breast Cancer Res 12: R83.

Kojima I, Maeshima A, Zhang YQ. 2001. Role of the activinfollistatin system in the morphogenesis and regeneration of the renal tubules. Mol Cell Endocrinol 180: 179-182.

Kowanetz M, Valcourt U, Bergstrom R, Heldin CH, Moustakas A. 2004. Id2 and Id3 define the potency of cell proliferation and differentiation responses to transforming growth factor $\beta$ and bone morphogenetic protein. Mol Cell Biol 24: 4241-4254.

Kusafuka K, Yamaguchi A, Kayano T, Takemura T. 2001. Immunohistochemical localization of members of the transforming growth factor (TGF)- $\beta$ superfamily in normal human salivary glands and pleomorphic adenomas. J Oral Pathol Med 30: 413-420.

Laiho M, Weis MB, Massagué J. 1990. Concomitant loss of transforming growth factor (TGF) $\beta$ receptor types I and II in TGF- $\beta$-resistant cell mutants implicates both receptor types in signal transduction. J Biol Chem 265: 1851818524.

Lamm ML, Podlasek CA, Barnett DH, Lee J, Clemens JQ, Hebner CM, Bushman W. 2001. Mesenchymal factor bone morphogenetic protein 4 restricts ductal budding and branching morphogenesis in the developing prostate. Dev Biol 232: 301-314.

Leight JL, Wozniak MA, Chen S, Lynch ML, Chen CS. 2012. Matrix rigidity regulates a switch between TGF- $\beta 1$-induced apoptosis and epithelial-mesenchymal transition. Mol Biol Cell 23: 781-791.

Li Q, Karam SM, Coerver KA, Matzuk MM, Gordon JI. 1998. Stimulation of activin receptor II signaling pathways inhibits differentiation of multiple gastric epithelial lineages. Mol Endocrinol 12: 181-192.

Li X, Wang Y, Sharif-Afshar AR, Uwamariya C, Yi A, Ishii K, Hayward SW, Matusik RJ, Bhowmick NA. 2009. Urothelial transdifferentiation to prostate epithelia is mediated by paracrine TGF- $\beta$ signaling. Differentiation 77: $95-$ 102.

Li Y, Eggermont K, Vanslembrouck V, Verfaillie CM. 2013. NKX2-1 activation by SMAD2 signaling after definitive endoderm differentiation in human embryonic stem cell. Stem Cells Dev 22: 1433-1442.

Li A, Ma S, Smith SM, Lee MK, Fischer A, Borok Z, Bellusci S, Li C, Minoo P. 2016. Mesodermal ALK5 controls lung 
K. Kahata et al.

myofibroblast versus lipofibroblast cell fate. BMC Biol 14: 19.

Lim J, Thiery JP. 2012. Epithelial-mesenchymal transitions: Insights from development. Development 139: 34713486.

Lima MJ, Muir KR, Docherty HM, Drummond R, McGowan NW, Forbes S, Heremans Y, Houbracken I, Ross JA, Forbes SJ, et al. 2013. Suppression of epithelial-to-mesenchymal transitioning enhances ex vivo reprogramming of human exocrine pancreatic tissue toward functional insulin-producing $\beta$-like cells. Diabetes 62: 2821-2833.

Liu J, Tseu I, Wang J, Tanswell K, Post M. 2000. Transforming growth factor $\beta 2$, but not $\beta 1$ and $\beta 3$, is critical for early rat lung branching. Dev Dyn 217: 343-360.

Long L, Ormiston ML, Yang X, Southwood M, Graf S, Machado RD, Mueller M, Kinzel B, Yung LM, Wilkinson JM, et al. 2015. Selective enhancement of endothelial BMPRII with BMP9 reverses pulmonary arterial hypertension. Nat Med 21: 777-785.

Lourenco SV, Uyekita SH, Lima DM, Soares FA. 2008. Developing human minor salivary glands: Morphological parallel relation between the expression of TGF- $\beta$ isoforms and cytoskeletal markers of glandular maturation. Virchows Arch 452: 427-434.

Lu MM, Yang H, Zhang L, Shu W, Blair DG, Morrisey EE. 2001. The bone morphogenic protein antagonist gremlin regulates proximal-distal patterning of the lung. Dev Dyn 222: 667-680.

Lv ZM, Wang Q, Wan Q, Lin JG, Hu MS, Liu YX, Wang R. 2011. The role of the p38 MAPK signaling pathway in high glucose-induced epithelial-mesenchymal transition of cultured human renal tubular epithelial cells. PLOS ONE 6: e22806.

Ma R, Latif R, Davies TF. 2009. Thyrotropin-independent induction of thyroid endoderm from embryonic stem cells by activin A. Endocrinology 150: 1970-1975.

Macias H, Hinck L. 2012. Mammary gland development. Wiley Interdiscip Rev Dev Biol 1: 533-557.

Maeshima A, Yamashita S, Maeshima K, Kojima I, Nojima Y 2003. Activin A produced by ureteric bud is a differentiation factor for metanephric mesenchyme. J Am Soc Nephrol 14: 1523-1534.

Maldonado TS, Kadison AS, Crisera CA, Grau JB, Alkasab SL, Longaker MT, Gittes GK. 2000. Ontogeny of activin B and follistatin in developing embryonic mouse pancreas: Implications for lineage selection. J Gastrointest Surg 4: 269-275.

Maloum F, Allaire JM, Gagne-Sansfacon J, Roy E, Belleville K, Sarret P, Morisset J, Carrier JC, Mishina Y, Kaestner $\mathrm{KH}$, et al. 2011. Epithelial BMP signaling is required for proper specification of epithelial cell lineages and gastric endocrine cells. Am J Physiol Gastrointest Liver Physiol 300: G1065-1079.

Marconett CN, Zhou B, Rieger ME, Selamat SA, Dubourd M, Fang X, Lynch SK, Stueve TR, Siegmund KD, Berman $\mathrm{BP}$, et al. 2013. Integrated transcriptomic and epigenomic analysis of primary human lung epithelial cell differentiation. PLoS Genet 9: e1003513.

Martinez G, Loveland KL, Clark AT, Dziadek M, Bertram JF. 2001. Expression of bone morphogenetic protein receptors in the developing mouse metanephros. Exp Nephrol 9: $372-379$.
Massagué J. 2012. TGF $\beta$ signalling in context. Nat Rev Mol Cell Biol 13: 616-630.

Masui T, Wakefield LM, Lechner JF, LaVeck MA, Sporn MB, Harris CC. 1986. Type $\beta$ transforming growth factor is the primary differentiation-inducing serum factor for normal human bronchial epithelial cells. Proc Natl Acad Sci 83: 2438-2442.

Matzuk MM, Kumar TR, Bradley A. 1995. Different phenotypes for mice deficient in either activins or activin receptor type II. Nature 374: 356-360.

McCracken KW, Cata EM, Crawford CM, Sinagoga KL, Schumacher M, Rockich BE, Tsai YH, Mayhew CN, Spence JR, Zavros Y, et al. 2014. Modelling human development and disease in pluripotent stem-cell-derived gastric organoids. Nature 516: 400-404.

McNairn AJ, Brusadelli M, Guasch G. 2013. Signaling moderation: TGF- $\beta$ in exocrine gland development, maintenance, and regulation. Eur J Dermatol doi: 10.1684/ ejd.2013.1979.

Meyer C, Liu Y, Kaul A, Peipe I, Dooley S. 2013. Caveolin-1 abrogates TGF- $\beta$ mediated hepatocyte apoptosis. Cell Death Dis 4: e466.

Michos O, Goncalves A, Lopez-Rios J, Tiecke E, Naillat F, Beier K, Galli A, Vainio S, Zeller R. 2007. Reduction of BMP4 activity by gremlin 1 enables ureteric bud outgrowth and GDNF/WNT11 feedback signalling during kidney branching morphogenesis. Development 134: 2397-2405.

Miralles F, Czernichow P, Scharfmann R. 1998. Follistatin regulates the relative proportions of endocrine versus exocrine tissue during pancreatic development. Development 125: 1017-1024.

Miyazaki Y, Oshima K, Fogo A, Hogan BL, Ichikawa I. 2000. Bone morphogenetic protein 4 regulates the budding site and elongation of the mouse ureter. J Clin Invest 105: 863-873.

* Miyazawa K, Miyazono K. 2016. Regulation of TGF- $\beta$ family signaling by inhibitory Smads. Cold Spring Harb Perspect Biol 9: a022095.

Molloy EL, Adams A, Moore JB, Masterson JC, MadrigalEstebas L, Mahon BP, O’Dea S. 2008. BMP4 induces an epithelial-mesenchymal transition-like response in adult airway epithelial cells. Growth Factors 26: 12-22.

Moniot B, Biau S, Faure S, Nielsen CM, Berta P, Roberts DJ, de Santa Barbara P. 2004. SOX9 specifies the pyloric sphincter epithelium through mesenchymal-epithelial signals. Development 131: 3795-3804.

Montesano R. 2007. Bone morphogenetic protein-4 abrogates lumen formation by mammary epithelial cells and promotes invasive growth. Biochem Biophys Res Commun 353: $817-822$.

Moustakas A, Heldin P. 2013. TGF $\beta$ and matrix-regulated epithelial to mesenchymal transition. Biochim Biophys Acta 1840: 2621-2634.

Nagy P, Evarts RP, McMahon JB, Thorgeirsson SS. 1989. Role of TGF- $\beta$ in normal differentiation and oncogenesis in rat liver. Mol Carcinog 2: 345-354.

* Namwanje M, Brown CW. 2016. Activins and inhibins: Roles in development, physiology, and disease. Cold Spring Harb Perspect Biol 8: a021881. 
TGF- $\beta$ Family Signaling in Ductal Biology

Narita T, Saitoh K, Kameda T, Kuroiwa A, Mizutani M, Koike C, Iba H, Yasugi S. 2000. BMPs are necessary for stomach gland formation in the chicken embryo: A study using virally induced BMP-2 and Noggin expression. Development 127: 981-988.

Nguyen AV, Pollard JW. 2000. Transforming growth factor $\beta 3$ induces cell death during the first stage of mammary gland involution. Development 127: 3107-3118.

Nguyen DH, Martinez-Ruiz H, Barcellos-Hoff MH. 2011. Consequences of epithelial or stromal TGF $\beta 1$ depletion in the mammary gland. J Mammary Gland Biol Neoplasia 16: $147-155$.

Nieto MA. 2009. Epithelial-mesenchymal transitions in development and disease: Old views and new perspectives. Int J Dev Biol 53: 1541-1547.

Nieto MA. 2013. Epithelial plasticity: A common theme in embryonic and cancer cells. Science 342: 1234850.

Ninomiya N, Michiue T, Asashima M, Kurisaki A. 2013. BMP signaling regulates the differentiation of mouse embryonic stem cells into lung epithelial cell lineages. In Vitro Cell Dev Biol Anim 49: 230-237.

Noguchi TK, Ninomiya N, Sekine M, Komazaki S, Wang PC, Asashima M, Kurisaki A. 2015. Generation of stomach tissue from mouse embryonic stem cells. Nat Cell Biol 17: 984-993.

Obara-Ishihara T, Kuhlman J, Niswander L, Herzlinger D. 1999. The surface ectoderm is essential for nephric duct formation in intermediate mesoderm. Development 126 $1103-1108$.

Ohgushi M, Kuroki S, Fukamachi H, O'Reilly LA, Kuida K, Strasser A, Yonehara S. 2005. Transforming growth factor $\beta$-dependent sequential activation of Smad, Bim, and caspase-9 mediates physiological apoptosis in gastric epithelial cells. Mol Cell Biol 25: 10017-10028.

Omori A, Miyagawa S, Ogino Y, Harada M, Ishii K, Sugimura Y, Ogino H, Nakagata N, Yamada G. 2014. Essential roles of epithelial bone morphogenetic protein signaling during prostatic development. Endocrinology 155: 25342544.

Oshimori N, Fuchs E. 2012. The harmonies played by TGF$\beta$ in stem cell biology. Cell Stem Cell 11: 751-764.

Oxburgh L, Chu GC, Michael SK, Robertson EJ. 2004. TGF $\beta$ superfamily signals are required for morphogenesis of the kidney mesenchyme progenitor population. Development 131: 4593-4605.

Patel VN, Rebustini IT, Hoffman MP. 2006. Salivary gland branching morphogenesis. Differentiation 74: 349-364.

Perotti C, Karayazi O, Moffat S, Shemanko CS. 2012. The bone morphogenetic protein receptor-1A pathway is required for lactogenic differentiation of mammary epithelial cells in vitro. In Vitro Cell Dev Biol Anim 48: 377-384.

Pierce DF Jr, Johnson MD, Matsui Y, Robinson SD, Gold LI, Purchio AF, Daniel CW, Hogan BL, Moses HL. 1993. Inhibition of mammary duct development but not alveolar outgrowth during pregnancy in transgenic mice expressing active TGF- $\beta 1$. Genes Dev 7: 2308-2317.

Piscione TD, Yager TD, Gupta IR, Grinfeld B, Pei Y, Attisano L, Wrana JL, Rosenblum ND. 1997. BMP-2 and OP-1 exert direct and opposite effects on renal branching morphogenesis. Am J Physiol 273: F961-975.
Que J, Choi M, Ziel JW, Klingensmith J, Hogan BL. 2006. Morphogenesis of the trachea and esophagus: Current players and new roles for noggin and Bmps. Differentiation 74: 422-437.

Raatikainen-Ahokas A, Hytonen M, Tenhunen A, Sainio K, Sariola H. 2000. BMP-4 affects the differentiation of metanephric mesenchyme and reveals an early anterior-posterior axis of the embryonic kidney. Dev Dyn 217: $146-158$.

Reidy KJ, Rosenblum ND. 2009. Cell and molecular biology of kidney development. Semin Nephrol 29: 321-337.

Ritvos O, Tuuri T, Eramaa M, Sainio K, Hilden K, Saxen L, Gilbert SF. 1995. Activin disrupts epithelial branching morphogenesis in developing glandular organs of the mouse. Mech Dev 50: 229-245.

Robinson SD, Roberts AB, Daniel CW. 1993. TGF $\beta$ suppresses casein synthesis in mouse mammary explants and may play a role in controlling milk levels during pregnancy. J Cell Biol 120: 245-251.

Romero-Gallo J, Sozmen EG, Chytil A, Russell WE, Whitehead R, Parks WT, Holdren MS, Her MF, Gautam S, Magnuson $\mathrm{M}$, et al. 2005. Inactivation of TGF- $\beta$ signaling in hepatocytes results in an increased proliferative response after partial hepatectomy. Oncogene 24: 30283041.

Saitoh M, Shirakihara T, Fukasawa A, Horiguchi K, Sakamoto K, Sugiya H, Beppu H, Fujita Y, Morita I, Miyazono $\mathrm{K}$, et al. 2013. Basolateral BMP signaling in polarized epithelial cells. PLoS ONE 8: e62659.

Salm SN, Burger PE, Coetzee S, Goto K, Moscatelli D, Wilson EL. 2005. TGF- $\beta$ maintains dormancy of prostatic stem cells in the proximal region of ducts. J Cell Biol 170: 81-90.

Sanchez A, Alvarez AM, Lopez Pedrosa JM, Roncero C, Benito M, Fabregat I. 1999. Apoptotic response to TGF- $\beta$ in fetal hepatocytes depends upon their state of differentiation. Exp Cell Res 252: 281-291.

Sanvito F, Herrera PL, Huarte J, Nichols A, Montesano R, Orci L, Vassalli JD. 1994. TGF- $\beta 1$ influences the relative development of the exocrine and endocrine pancreas in vitro. Development 120: 3451-3462.

Schuster N, Krieglstein K. 2002. Mechanisms of TGF- $\beta$-mediated apoptosis. Cell Tissue Res 307: 1-14.

Serra R, Pelton RW, Moses HL. 1994. TGF- $\beta 1$ inhibits branching morphogenesis and $\mathrm{N}$-myc expression in lung bud organ cultures. Development 120: 2153-2161.

Settle S, Marker P, Gurley K, Sinha A, Thacker A, Wang Y, Higgins K, Cunha G, Kingsley DM. 2001. The BMP family member Gdf7 is required for seminal vesicle growth, branching morphogenesis, and cytodifferentiation. Dev Biol 234: 138-150.

Shi W, Zhao J, Anderson KD, Warburton D. 2001. Gremlin negatively modulates BMP-4 induction of embryonic mouse lung branching morphogenesis. Am J Physiol Lung Cell Mol Physiol 280: L1030-1039.

Shi W, Chen H, Sun J, Chen C, Zhao J, Wang YL, Anderson KD, Warburton D. 2004. Overexpression of Smurf1 negatively regulates mouse embryonic lung branching morphogenesis by specifically reducing Smad1 and Smad5 proteins. Am J Physiol Lung Cell Mol Physiol 286: L293-300. 
K. Kahata et al.

Shin JA, Hong OK, Lee HJ, Jeon SY, Kim JW, Lee SH, Cho JH, Lee JM, Choi YH, Chang SA, et al. 2011. Transforming growth factor- $\beta$ induces epithelial to mesenchymal transition and suppresses the proliferation and transdifferentiation of cultured human pancreatic duct cells. $J$ Cell Biochem 112: 179-188.

Shinohara M, Mao M, Keeley TM, El-Zaatari M, Lee HJ, Eaton KA, Samuelson LC, Merchant JL, Goldenring JR, Todisco A. 2010. Bone morphogenetic protein signaling regulates gastric epithelial cell development and proliferation in mice. Gastroenterology 139: 2050-2060.e2.

Shiozaki S, Tajima T, Zhang YQ, Furukawa M, Nakazato Y, Kojima I. 1999. Impaired differentiation of endocrine and exocrine cells of the pancreas in transgenic mouse expressing the truncated type II activin receptor. Biochim Biophys Acta 1450: 1-11.

Silberstein GB, Daniel CW. 1987. Reversible inhibition of mammary gland growth by transforming growth factor- $\beta$. Science 237: 291-293.

Sims-Lucas S, Caruana G, Dowling J, Kett MM, Bertram JF. 2008. Augmented and accelerated nephrogenesis in TGF$\beta 2$ heterozygous mutant mice. Pediatr Res 63: 607-612.

Sountoulidis A, Stavropoulos A, Giaglis S, Apostolou E Monteiro R, Chuva de Sousa Lopes SM, Chen H, Stripp BR, Mummery C, Andreakos E, et al. 2012. Activation of the canonical bone morphogenetic protein (BMP) pathway during lung morphogenesis and adult lung tissue repair. PLoS ONE 7: e41460.

Sun J, Chen H, Chen C, Whitsett JA, Mishina Y, Bringas PJr, Ma JC, Warburton D, Shi W. 2008. Prenatal lung epithelial cell-specific abrogation of Alk3-bone morphogenetic protein signaling causes neonatal respiratory distress by disrupting distal airway formation. Am J Pathol 172: $571-582$.

Suzuki Y, Ohga N, Morishita Y, Hida K, Miyazono K, Watabe T. 2010. BMP-9 induces proliferation of multiple types of endothelial cells in vitro and in vivo. J Cell Sci 123: $1684-$ 1692.

Tadokoro T, Gao X, Hong CC, Hotten D, Hogan BL. 2016. BMP signaling and cellular dynamics during regeneration of airway epithelium from basal progenitors. Development 143: 764-773.

Thomson AA, Marker PC. 2006. Branching morphogenesis in the prostate gland and seminal vesicles. Differentiation 74: 382-392.

Timme TL, Yang G, Rogers E, Kadmon D, Morganstern JP, Park SH, Thompson TC. 1996. Retroviral transduction of transforming growth factor- $\beta 1$ induces pleiotropic benign prostatic growth abnormalities in mouse prostate reconstitutions. Lab Invest 74: 747-760.

Todisco A, Mao M, Keeley TM, Ye W, Samuelson LC, Eaton KA. 2015. Regulation of gastric epithelial cell homeostasis by gastrin and bone morphogenetic protein signaling. Physiol Rep 3: pii: e12501.

Tomlinson DC, Freestone SH, Grace OC, Thomson AA. 2004. Differential effects of transforming growth factor$\beta 1$ on cellular proliferation in the developing prostate. Endocrinology 145: 4292-4300.

Tremblay KD. 2011. Inducing the liver: Understanding the signals that promote murine liver budding. J Cell Physiol 226: $1727-1731$.
Tripathi P, Wang Y, Casey AM, Chen F. 2012. Absence of canonical Smad signaling in ureteral and bladder mesenchyme causes ureteropelvic junction obstruction. J Am Soc Nephrol 23: 618-628.

Tsugawa D, Oya Y, Masuzaki R, Ray K, Engers DW, Dib M, Do N, Kuramitsu K, Ho K, Frist A, et al. 2014. Specific activin receptor-like kinase 3 inhibitors enhance liver regeneration. J Pharmacol Exp Ther 351: 549-558.

Tsukada T, Azuma M, Horiguchi K, Fujiwara K, Kouki T, Kikuchi M, Yashiro T. 2016. Folliculostellate cell interacts with pericyte via TGF $\beta 2$ in rat anterior pituitary. J Endocrinol 229: 159-170.

Tucker RF, Shipley GD, Moses HL, Holley RW. 1984. Growth inhibitor from BSC-1 cells closely related to platelet type $\beta$ transforming growth factor. Science 226: 705-707.

Tulachan SS, Tei E, Hembree M, Crisera C, Prasadan K, Koizumi M, Shah S, Guo P, Böttinger E, Gittes GK. 2007. TGF- $\beta$ isoform signaling regulates secondary transition and mesenchymal-induced endocrine development in the embryonic mouse pancreas. Dev Biol 305: 508-521.

Undevia NS, Dorscheid DR, Marroquin BA, Gugliotta WL, Tse R, White SR. 2004. Smad and p38-MAPK signaling mediates apoptotic effects of transforming growth factor$\beta 1$ in human airway epithelial cells. Am J Physiol Lung Cell Mol Physiol 287: L515-524.

Valdés F, Alvarez AM, Locascio A, Vega S, Herrera B, Fernandez M, Benito M, Nieto MA, Fabregat I. 2002. The epithelial mesenchymal transition confers resistance to the apoptotic effects of transforming growth factor $\beta$ in fetal rat hepatocytes. Mol Cancer Res 1: 68-78.

Valdez JM, Zhang L, Su Q, Dakhova O, Zhang Y, Shahi P, Spencer DM, Creighton CJ, Ittmann MM, Xin L. 2012. Notch and TGF $\beta$ form a reciprocal positive regulatory loop that suppresses murine prostate basal stem/progenitor cell activity. Cell Stem Cell 11: 676-688.

van Eyll JM, Pierreux CE, Lemaigre FP, Rousseau GG. 2004. Shh-dependent differentiation of intestinal tissue from embryonic pancreas by activin A. J Cell Sci 117: $2077-$ 2086.

Veerasamy M, Phanish M, Dockrell ME. 2013. Smad mediated regulation of inhibitor of DNA binding 2 and its role in phenotypic maintenance of human renal proximal tubule epithelial cells. PLOS ONE 8: e51842.

Villacorte M, Delmarcelle AS, Lernoux M, Bouquet M, Lemoine P, Bolsee J, Umans L, de Sousa Lopes SC, Van Der Smissen P, Sasaki T, et al. 2016. Thyroid follicle development requires Smad1/Smad5- and endothelial-dependent basement membrane assembly. Development 143: 1958-1970.

Wakefield LM, Piek E, Böttinger EP. 2001. TGF- $\beta$ signaling in mammary gland development and tumorigenesis. $J$ Mammary Gland Biol Neoplasia 6: 67-82.

Walker KA, Sims-Lucas S, Caruana G, Cullen-McEwen L, Li J, Sarraj MA, Bertram JF, Stenvers KL. 2011. Betaglycan is required for the establishment of nephron endowment in the mouse. PLoS ONE 6: e18723.

Walton KD, Whidden M, Kolterud A, Shoffner KS, Czerwinski MJ, Kushwaha J, Parmar N, Chandhrasekhar D, Freddo AM, Schnell S, et al. 2016. Villification in the mouse: Bmp signals control intestinal villus patterning. Development 143: 427-436. 
Watanabe K, Villarreal-Ponce A, Sun P, Salmans ML, Fallahi M, Andersen B, Dai X. 2014. Mammary morphogenesis and regeneration require the inhibition of EMT at terminal end buds by Ovol2 transcriptional repressor. Dev Cell 29: $59-74$.

Weaver M, Yingling JM, Dunn NR, Bellusci S, Hogan BL. 1999. Bmp signaling regulates proximal-distal differentiation of endoderm in mouse lung development. Development 126: 4005-4015.

Weber H, Holewa B, Jones EA, Ryffel GU. 1996. Mesoderm and endoderm differentiation in animal cap explants: Identification of the HNF4-binding site as an activin A responsive element in the Xenopus HNF1 $\alpha$ promoter. Development 122: 1975-1984.

Xing Y, Li C, Hu L, Tiozzo C, Li M, Chai Y, Bellusci S, Anderson S, Minoo P. 2008. Mechanisms of TGF $\beta$ inhibition of LUNG endodermal morphogenesis: The role of TßRII, Smads, Nkx2.1 and Pten. Dev Biol 320: 340-350.

Xing Y, Li C, Li A, Sridurongrit S, Tiozzo C, Bellusci S, Borok Z, Kaartinen V, Minoo P. 2010. Signaling via Alk5 controls the ontogeny of lung Clara cells. Development 137: 825 833.

Xu Y, Wan J, Jiang D, Wu X. 2009. BMP-7 counteracts TGF$\beta 1$-induced epithelial-to-mesenchymal transition in human renal proximal tubular epithelial cells. J Nephrol 22: 403-410.

Xu B, Chen C, Chen H, Zheng SG, Bringas PJr, Xu M, Zhou X, Chen D, Umans L, Zwijsen A, et al. 2011. Smad1 and its target gene Wif1 coordinate BMP and Wnt signaling activities to regulate fetal lung development. Development 138: 925-935.

Xu Y, Yang S, Huang J, Ruan S, Zheng Z, Lin J. 2012. TGF- $\beta 1$ induces autophagy and promotes apoptosis in renal tubular epithelial cells. Int J Mol Med 29: 781-790.

Yamaoka T, Idehara C, Yano M, Matsushita T, Yamada T, Ii S, Moritani M, Hata J, Sugino H, Noji S, et al. 1998. Hypoplasia of pancreatic islets in transgenic mice expressing activin receptor mutants. J Clin Invest 102: 294-301.

Yanai M, Tatsumi N, Hasunuma N, Katsu K, Endo F, Yokouchi Y. 2008. FGF signaling segregates biliary cell-lineage from chick hepatoblasts cooperatively with BMP4 and ECM components in vitro. Dev Dyn 237: 1268-1283.

Yang Y, Pan X, Lei W, Wang J, Shi J, Li F, Song J. 2006. Regulation of transforming growth factor- $\beta 1$-induced apoptosis and epithelial-to-mesenchymal transition by protein kinase A and signal transducers and activators of transcription 3. Cancer Res 66: 8617-8624.

Yu S, Fang Y, Sharp GC, Braley-Mullen H. 2010. Transgenic expression of TGF- $\beta$ on thyrocytes inhibits development of spontaneous autoimmune thyroiditis and increases regulatory T cells in thyroids of NOD.H-2h4 mice. J Immunol 184: 5352-5359.

Zeisberg M, Hanai J, Sugimoto H, Mammoto T, Charytan D, Strutz F, Kalluri R. 2003. BMP-7 counteracts TGF- $\beta 1$ induced epithelial-to-mesenchymal transition and reverses chronic renal injury. Nat Med 9: 964-968.

Zhang YQ, Cleary MM, Si Y, Liu G, Eto Y, Kritzik M, Dabernat S, Kayali AG, Sarvetnick N. 2004. Inhibition of activin signaling induces pancreatic epithelial cell expansion and diminishes terminal differentiation of pancreatic $\beta$-cells. Diabetes 53: 2024-2033.

Zhang P, Cai Y, Soofi A, Dressler GR. 2012. Activation of Wnt11 by transforming growth factor- $\beta$ drives mesenchymal gene expression through non-canonical Wnt protein signaling in renal epithelial cells. J Biol Chem 287: 21290-21302.

Zhao J, Lee M, Smith S, Warburton D. 1998. Abrogation of Smad 3 and Smad 2 or of Smad4 gene expression positively regulates murine embryonic lung branching morphogenesis in culture. Dev Biol 194: 182-195.

Zhao J, Shi W, Chen H, Warburton D. 2000. Smad7 and Smad6 differentially modulate transforming growth factor $\beta$-induced inhibition of embryonic lung morphogenesis. J Biol Chem 275: 23992-23997.

Zhou B, Liu Y, Kahn M, Ann DK, Han A, Wang H, Nguyen C, Flodby P, Zhong Q, Krishnaveni MS, et al. 2012. Interactions between $\beta$-catenin and transforming growth factor- $\beta$ signaling pathways mediate epithelial-mesenchymal transition and are dependent on the transcriptional co-activator cAMP-response element-binding protein (CREB)-binding protein (CBP). J Biol Chem 287: 7026-7038.

Zhu L, Wang L, Wang X, Luo X, Yang L, Zhang R, Yin H, Xie D, Pan Y, Chen Y. 2011. Hepatic deletion of Smad7 in mouse leads to spontaneous liver dysfunction and aggravates alcoholic liver injury. PLoS ONE 6: e17415. 


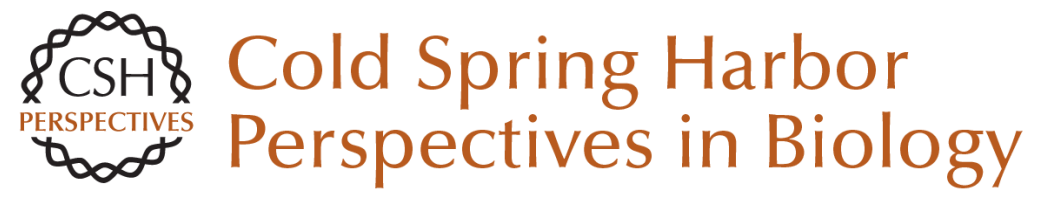

\section{TGF- $\beta$ Family Signaling in Ductal Differentiation and Branching Morphogenesis}

Kaoru Kahata, Varun Maturi and Aristidis Moustakas

Cold Spring Harb Perspect Biol 2018; doi: 10.1101/cshperspect.a031997 originally published online March 13, 2017

Subject Collection The Biology of the TGF-\&\#946; Family

TGF- $\beta$ Family Signaling in Early Vertebrate

Development

Joseph Zinski, Benjamin Tajer and Mary C. Mullins

Bone Morphogenetic Protein-Based Therapeutic

Approaches

Jonathan W. Lowery and Vicki Rosen

TGF- $\beta$ Family Signaling in Ductal Differentiation

and Branching Morphogenesis

Kaoru Kahata, Varun Maturi and Aristidis

Moustakas

TGF- $\beta$ Signaling in Control of Cardiovascular

Function

Marie-José Goumans and Peter ten Dijke

TGF- $\beta$ Family Signaling in Tumor Suppression and Cancer Progression

Joan Seoane and Roger R. Gomis

Targeting TGF- $\beta$ Signaling for Therapeutic Gain Rosemary J. Akhurst

Regulation of Hematopoiesis and Hematological Disease by TGF- $\beta$ Family Signaling Molecules Kazuhito Naka and Atsushi Hirao
TGF- $\beta$ Family Signaling in Mesenchymal

Differentiation

Ingo Grafe, Stefanie Alexander, Jonathan $R$.

Peterson, et al.

TGF- $\beta 1$ Signaling and Tissue Fibrosis

Kevin K. Kim, Dean Sheppard and Harold A.

Chapman

Bone Morphogenetic Proteins in Vascular

Homeostasis and Disease

Marie-José Goumans, An Zwijsen, Peter ten Dijke, et al.

TGF- $\beta$ Family Signaling in Epithelial

Differentiation and Epithelial-Mesenchymal

Transition

Kaoru Kahata, Mahsa Shahidi Dadras and Aristidis Moustakas

TGF- $\beta$ Family Signaling in Connective Tissue and

Skeletal Diseases

Elena Gallo MacFarlane, Julia Haupt, Harry C.

Dietz, et al.

The TGF- $\beta$ Family in the Reproductive Tract

Diana Monsivais, Martin M. Matzuk and Stephanie A. Pangas

TGF- $\beta$ Family Signaling in Drosophila Ambuj Upadhyay, Lindsay Moss-Taylor, Myung-Jun Kim, et al.

For additional articles in this collection, see http://cshperspectives.cshlp.org/cgi/collection/

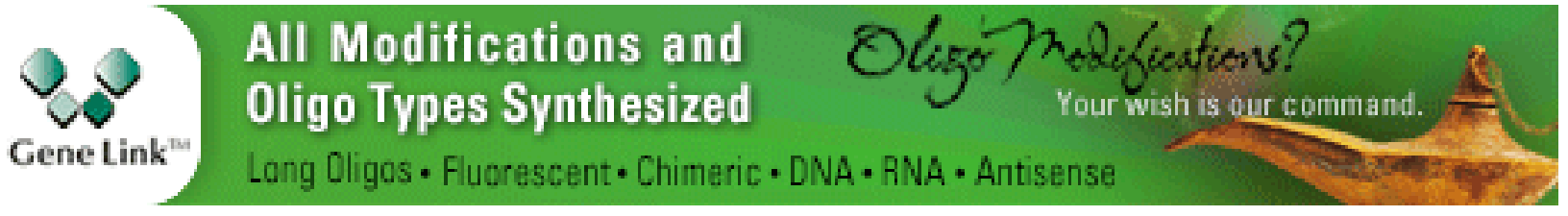


TGF- $\beta$ Family Signaling in Neural and Neuronal Differentiation, Development, and Function Emily A. Meyers and John A. Kessler
Signaling Cross Talk between TGF- $\beta /$ Smad and Other Signaling Pathways Kunxin LuO

For additional articles in this collection, see http://cshperspectives.cshlp.org/cgi/collection/

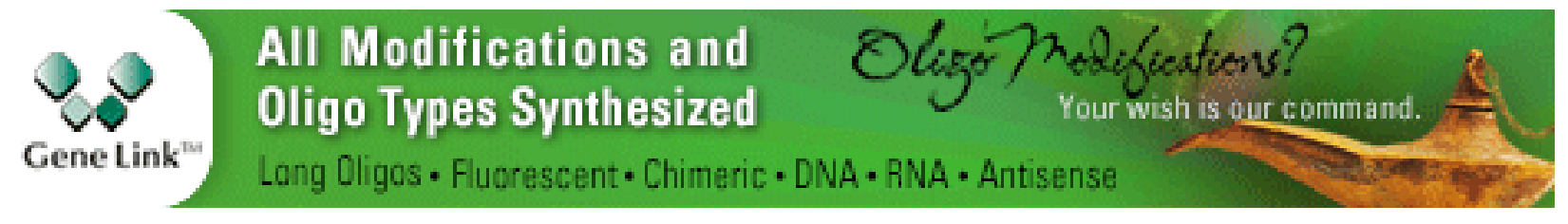

Copyright @ 2018 Cold Spring Harbor Laboratory Press; all rights reserved 